\title{
Seasonality of floral resources in relation to bee activity in agroecosystems
}

\author{
Jessica Guezen ${ }^{1}$ and Jessica R. K. Forrest ${ }^{1}$ \\ ${ }^{1}$ University of Ottawa
}

May 26, 2020

\begin{abstract}
The contribution of wild insects to crop pollination is becoming increasingly important as global demand for crops dependent on animal pollination increases. If wild insect populations are to persist in agricultural landscapes, there must be sufficient floral resources (FR) over time and space. The temporal, within-season component of FR availability has rarely been investigated, despite growing recognition of its likely importance for pollinator populations. Here, we examined the visitation rates of common bee genera and the spatiotemporal availability of FR in agroecosystems over one season to determine whether local bee activity was limited by the abundance of landscape FR, and if so, whether it was limited by the present or past abundance of landscape FR. Visitation rates and landscape FR were measured in 27 agricultural sites in Ontario and Québec, Canada, across four time periods and three spatial scales. Landscape FR at varying spatial scales predicted visits for the seven most commonly observed bee genera. Bombus visitation rates were higher in landscapes that had greater cumulative seasonal abundance of FR, suggesting the importance of early-season FR for this taxon. Visits from Halictus and Lasioglossum were higher in landscapes that provided either a stable or increasing amount of FR over the season and were lower in landscapes that experienced a decrease in FR over the course of a season. Andrena, Augochlorella, Megachile, and Peponapis visits were not measurably influenced by FR in previous months but were lower in landscapes that had a higher present abundance of FR, perhaps reflecting pollinator movement or dilution. Our research provides insight into how seasonal fluctuations in floral resources affect bee activity, and by examining each bee genus separately, we could observe how differences in foraging periods, foraging ranges, and the number of broods per season influence how bee taxa respond to food availability within agroecosystems.
\end{abstract}

\section{Keywords}

Anthophila, agricultural landscape, floral volume, pollinators, spatiotemporal scale

\section{Introduction}

The abundance and accessibility of floral resources (hereafter, 'FR') has been identified as the primary factor limiting wild bee populations globally (Roulston and Goodell 2011). Specifically, if wild bee populations are to persist, there must be sufficient provision of FR over both time and space. However, extensive conversion of natural habitat to arable land to support the growing human population is resulting in the removal of many of the naturally occurring FR on which wild bee populations rely (Kremen et al. 2002, Brosi et al. 2008, Murray et al. 2009). Even if crops themselves provide FR, they do so for only a portion of the growing season, which may be insufficient to support bee populations throughout their activity periods. An abundance of research looking at spatial provisioning of floral resources has generally found that increasing either heterogeneity or abundance of FR will result in increased population sizes or visitation rates of wild bees (synthesized in Kennedy et al. 2013). However, a few recent studies have found the opposite, with certain FR-providing habitats actually distracting bees from visiting crop fields (Nicholson et al. 2019), or causing a dilution of pollinators across landscapes when floral resources are less limited (Kovács-Hostyánszki et al. 2013, Holzschuh et al. 2016). 
While the influence of spatial arrangement of FR on bees foraging in agricultural landscapes has been well established, the influence of FR availability over time has been relatively understudied. Much of the existing research on the latter topic has found that in landscapes providing a consistent source of FR over time, wild bees respond positively in terms of their abundance (Mandelik et al. 2012, Mallinger et al. 2016, Martins et al. 2018), density in crops (Kovács-Hostyánszki et al. 2013), colony growth (Westphal et al. 2009, Crone and Williams 2016), and sexual reproduction (Rundlöf et al. 2014). However, most studies examining the effect of temporal and spatial arrangement of FR on bees focus on responses of abundant, social taxa such as honey bees (Lau et al. 2019) and bumble bees (Timberlake et al. 2019), or examine the responses of broad functional groups of bees, often by grouping solitary bees together (Le Féon et al. 2013, Kovács-Hostyánszki et al. 2013). An increase in bee population size or density in landscapes with high FR can only be observed within one season if bees produce multiple broods per season, or if there is immigration from adjacent landscapes. For wild bee species that have limited flight distances and produce a single brood annually -as is the case for most species in temperate regions-we would expect population sizes to remain stable when FR abundance is consistent or increases over a season, and to decrease in response to periods in a season when resources become scarce. Given the differences in brood production, foraging periods, and foraging ranges among bee taxa, fluctuations in FR should produce a diversity of responses (Ogilvie and Forrest 2017). We therefore expect that the spatial and temporal scale of FR that most influences bee population size should be specific to the taxonomic group of bees that is examined. Understanding the responses of specific bee taxa to seasonal FR in agricultural landscapes is important for development of conservation and management strategies that can both enhance pollination services and preserve bee functional diversity.

The objective of this study was to examine the relationship between visitation rates of bees and the amount of FR in agricultural landscapes over one season, to determine at which within-year temporal scale and landscape spatial scale the abundance of FR predicts local bee abundance. We examined visitation rates of the most common genera of bees and the corresponding amount of FR in surrounding agricultural landscapes in four sequential time periods over one season, to assess the relative support for the following hypotheses for each genus (presented in Fig. 1):

H1: Bee visits are only influenced by local FR - for bee populations that are limited by something other than FR (e.g., nesting habitat, pesticides, natural enemies), population sizes should not be correlated with the amount of FR in the broader landscape; instead, we expect that the present abundance of local FR (i.e., within the area in which bee visits are measured) will best predict local visitation rates.

H2: Bee visits are influenced by the present abundance of landscape FR - for bee populations that are influenced by the availability of FR, but that have relatively short foraging periods within a season (overlapping only one time period in which FR were measured), we expect that the present abundance of FR within the landscape will best predict bee visits, and that either (a)bees are limited by FR, so that in landscapes with higher FR abundance more bee visits will be observed; or that (b) bees are not limited by FR, but instead are "diluted" (dispersed) across landscapes with higher FR abundance, in which case fewer bee visits will be observed at a local flower patch.

H3: Bee visits are influenced by the previous abundance of landscape FR - for bee populations that are influenced by FR and have long foraging periods within a season (overlapping multiple time periods in which FR were measured), we expect that (a) for bees producing a single brood per season, both the abundance of FR in the landscape when foraging begins and any decreases in the abundance of FR later in the season will best predict bee visits; or (b) for bees producing multiple broods per season, the cumulative abundance of landscape FR from when foraging begins will best predict bee visits.

\section{Materials and methods}

Study sites and landscape structure

The study was conducted in 27 farms growing fruit or vegetable crops in Eastern Ontario and the Outaouais region of Québec, Canada. Farms planning to grow cucurbit crops were chosen initially for inclusion because we wished to focus on pollinator-dependent, late-season crops; however, many farms were not able to grow 
cucurbits due to drought conditions experienced throughout the region. To maximize independence among farm sites (i.e., to minimize the chance that an individual bee could move between farms), chosen farms were 4-211 km apart. Across all farm sites, 102 locations were sampled for bees and FR abundance (as described below), with one to six locations per farm, depending on the number of distinct land patches in which resource-providing flowers were present, and when permission was given from landowners. Sampling locations within patches of land were selected based on the estimated location of the patch's centre, or, if the patch was over $25 \mathrm{~m}$ wide, was located at least $10 \mathrm{~m}$ from an edge. In three patches wider than $25 \mathrm{~m}$, sampling locations less than $10 \mathrm{~m}$ from the edge were used due to a complete absence of flowers in bloom in the centre. The distance between sampling locations within a farm ranged from $3.8 \mathrm{~m}$ to $1040 \mathrm{~m}$. Sites were visited in rotation over four time periods during one season in 2016: the first took place between May 20-June 10 ( $\mathrm{n}=38$ sampling locations), the second from June 10-July $4(\mathrm{n}=33)$, the third from July 5 -August $1(\mathrm{n}=37)$, and the fourth from August 1-September $1(\mathrm{n}=39)$. If sampling locations contained open flowers during more than one sampling period, the same location was sampled in multiple time periods.

The composition of the landscape within $250 \mathrm{~m}, 500 \mathrm{~m}$, and $750 \mathrm{~m}$ radii of each sampling location was quantified to estimate landscape-scale FR abundance. The $250-750 \mathrm{~m}$ scale has been found in previous studies to be the range at which non-Apis bees respond to landscape structure (Steffan-Dewenter et al. 2002), and $500 \mathrm{~m}$ was chosen as an intermediate spatial scale. Sampling locations within the same farm site (and with overlapping radii at the $750 \mathrm{~m}$ scale) were not treated as independent (see Statistical analysis). Within a $750 \mathrm{~m}$ radius around each sampling location, the boundaries between land patches were manually digitized in QGIS version 2.18.7, using both waypoints taken on-site with a Trimble? Juno SD handheld GPS unit (Trimble Navigation Limited, Westminster, CO, USA), and from Google Earth and Bing Aerial satellite imagery.

Each land patch was then categorized by the type of land-use (hereafter, "land type"), through groundtruthing and raster imagery from Agriculture and Agri-Food Canada's (AAFC) 2016 Annual Crop Inventory. Land types fell into three categories: non-resource land, resource-providing land, and unknown land (see Appendix Table A1, Supporting Information, for detailed descriptions of each land type). Non-resource land was defined as any area that did not provide FR, which included crops with exclusively wind-pollinated flowers and crops with anecdotal or no evidence of bees collecting resources from flowers. Urban and developed land was also included in non-resource land; although urban gardens or lawns may provide FR for bees, the amount is inconsistent over time and space, and the number of bee species supported is usually low (Cane 2005, Matteson et al. 2008). Resource-providing land was defined as land areas that provided FR for bees at some point during the season and was categorized into 14 different land types (Appendix Table A1). Sampling locations were located only within resource-providing land, and at least one of each resourceproviding land type was sampled during each time period. Unknown land was comprised of areas where we could not determine the crop grown (2.3\% of all area surrounding sampling locations); hedgerow (1.8\%); or crop land where potentially resource-providing crops were grown, but FR were not measured $(0.7 \%)$. The total area of each land type was then calculated within radii of 250,500 , and $750 \mathrm{~m}$ around each sampling location.

\section{Bee observations}

Bee observation methods were adapted from frequently used pollinator surveying designs (Memmott 1999, Alarcon et al. 2008, Gibson et al. 2011). At each sampling location, a transect was set up to survey bee activity within a $30 \mathrm{~m} \mathrm{x} 4 \mathrm{~m}$ area (89 transects); a $30 \mathrm{~m} \mathrm{x} 2 \mathrm{~m}$ area was surveyed when only one crop row ( $<4 \mathrm{~m}$ wide) was present (eight transects); and $25 \mathrm{~m} \mathrm{x} 4 \mathrm{~m}$ (one transect) or $24 \mathrm{~m} \mathrm{x} 4 \mathrm{~m}$ areas (four transects) were surveyed when crop rows were shorter than $30 \mathrm{~m}$. Bee observations occurred over one minute per $4 \mathrm{~m}^{2}$ of transect intervals by slowly walking the length of the transect. The shaded and unshaded temperature, maximum wind speed, and average wind speed were recorded for at least one minute using a Kestrel? 2000 Pocket Weather? Meter (Nielsen-Kellerman, Boothwyn, PA, USA) held at approximately 1.5 $\mathrm{m}$ above ground preceding each observation period. If there was a noticeable change in conditions during the observation period, temperature and wind speed were recorded again at the end of the period and averages 
were recorded. All bee observations were conducted when shaded temperatures were above 11.9degC, average wind speeds were below $1.9 \mathrm{~m} / \mathrm{s}$, and maximum wind speeds were below $4 \mathrm{~m} / \mathrm{s}$.

During observation periods, all occurrences of bees visiting open flowers were recorded by two observers, standing on either side of the transect width, and recording all visits within $2 \mathrm{~m}$ each. A visit was counted when a bee was seen contacting sexual organs of an entomophilous flower or was probing a flower for nectar. All visited flowers were identified to genus (9 out of 77 taxa) or species (68 out of 77 taxa), and bees were identified on the wing to genus or species. When identification was not possible on the wing, the observations were paused and both observers attempted to catch the bee to take a photograph from inside a glass vial or to collect as a voucher (79 specimens total). Vouchers were then identified to species or genus and are stored in the Forrest lab's collection at the University of Ottawa (Ottawa, ON, Canada). Overall, $82 \%$ of bees were identified to species, $17 \%$ to genus, $0.1 \%$ to family, and $1 \%$ as Anthophila.

\section{Floral resources}

Floral density was recorded at each sampling location, using three quadrats of $1.5 \mathrm{~m} \mathrm{x} 1.5 \mathrm{~m}$. Quadrats were placed in random locations within the same transect used for bee observations, immediately following the observation period. If no open flowers were present in all three quadrat locations, an additional location was randomly selected and the mean count across the four quadrats was recorded. Within a quadrat, the number of open flowers was counted for each non-graminoid species encountered; for species with manyflowered inflorescences, five individuals were haphazardly selected, and the number of flowers was counted on a randomly selected inflorescence. The mean number of flowers per inflorescence for many-flowered species was then multiplied by the number of inflorescences in a quadrat to obtain the number of flowers per quadrat. In members of the Asteraceae family, capitula were treated as single flowers (see Appendix Table A2 for descriptions of floral units used for counts of each species). For 29 out of 96 species encountered, the number of flowers per inflorescence was obtained from either literature sources or digital images of herbarium specimens due to the large number of flowers encountered in the field, and for a few species that inadvertently were not measured in the field (see Appendix Table A2 for literature values for each species).

To estimate the amount of FR (nectar and pollen) provided by a species, floral dimensions were measured on five haphazardly selected individuals of each species. The length and width of the receptacle (or capitulum in Asteraceae species) were measured at right angles to each other, as well as the height from the receptacle to the end of the longest sexual organ (stamen or pistil); in species with sexual organs completely hidden within a corolla, height was measured from the receptacle to the end of the corolla. Measurements were made using calipers and were rounded to the nearest $1 \mathrm{~mm}$. Thirty-one of 96 species were not measured in the field, and floral measurements were instead obtained from literature sources or digital images of herbarium specimens (see Appendix Table A2 for measurements and literature sources for each species). Floral measurements were used to calculate both the surface area $(A)$ of flowers:

$$
\overline{\mathrm{A}=\pi \mathrm{ab} \quad(1)}
$$

and the volume $(V)$ of flowers:

$$
\overline{\mathrm{V}=\pi \mathrm{abh} \quad(2)}
$$

where $a$ is the semi-major axis, or half the length or width (whichever was longest) of a flower's receptacle or capitulum, $b$ is the semi-minor axis, or half the length or width (whichever was shortest) of a flower's receptacle or capitulum, and $h$ is the height of a flower or inflorescence (Fig 2c and Appendix Table A2).

To determine which measurement of floral dimensions was the best proxy for FR amount, literature searches for daily nectar sugar mass ( $\mu \mathrm{g} /$ day) and pollen volume (in $\mu \mathrm{l} /$ flower) were conducted for all flowering species encountered; these measurements have been previously used to assess FR available to pollinators (Hicks et 
al. 2016, Baude et al. 2016). Literature sources that provided counts of pollen grains per flower and volumes of individual pollen grains were used to calculate an estimate of pollen volume per flower for species for which we could not find measurements of total pollen volume. Nectar sugar mass was obtained for 46 species and pollen volume for 33 species of the 96 encountered (see Appendix Tables A3-A4 for full species lists). Pearson correlations between nectar sugar mass or pollen volume and the length, width, height, surface area, and volume measurements of each species (all variables log-transformed to approximate normal distributions) were used to determine which floral dimension could best estimate the amount of FR.

For all bee genera other than Peponapis, the abundance of FR in the landscape surrounding each sampling location was calculated by determining the mean FR value per flower of each species and multiplying this value by the count of each flower in a quadrat. In the genusPeponapis, pollen is collected exclusively from Cucurbitaspp. (Hurd et al. 1974). Therefore, in models of Peponapisvisits, the abundance of FR in the landscape surrounding each sampling location was calculated from the mean FR value per squash (Cucurbita spp.) or cucumber (Cucumis sativus ) flower, since $99.7 \%$ of all visits observed were to squash and $0.3 \%$ were to cucumber. While the other bee genera we considered include some oligolectic (pollen-specialist) species in our study area, they are not uniformly specialized on a single plant taxon, so all rewarding plant taxa were included in calculations of FR for these bees. The mean abundance of FR per $1 \mathrm{~m}^{2}$ was then calculated across quadrats for each transect, and the median of the transect-level values was calculated for each land type during each time period. This number was then multiplied by the total area of each land type within $250 \mathrm{~m}, 500 \mathrm{~m}$, and $750 \mathrm{~m}$ around a sampling location to obtain an estimate of the total FR at a given spatial scale during a given time period.

Statistical analysis

All statistical analyses were performed in $\mathrm{R}$ version 3.6.1 ( $\mathrm{R}$ Core Team 2019). Analyses of bee visitation rate per transect were conducted on bee genera that were present in at least four out of 27 sites during a given time period. Spatial autocorrelation among sites in the number of visits by each genus in a given time period was assessed using Moran's I (Paradis et al. 2004). Visits from Apis mellifera were found to be spatially autocorrelated across all time periods $(\mathrm{p}=0.02$, Moran's I $\mid$ observed - expected $\mid=0.14$ ), likely due to the presence of hives on certain farms, so were not analyzed.

Generalized linear mixed models were run with a zero-inflated negative binomial distribution and log link function, using the glmmTMB package (Brooks et al. 2017). Models treated the total number of bee visits observed within a transect as the response variable and were run separately for each genus; all models included a $\log$ offset to account for varying lengths of observation time based on transect sizes, and the crossed random effects of time period and site. For genera that were present in at least four sites in only a subset of the time periods, only models including data for those time periods were run. The model for the null hypothesis was of the form

\begin{tabular}{l}
$\overline{\text { Visits }_{\mathrm{ijk}}=1+\text { Site }_{\mathrm{j}}+\text { Time }_{\mathrm{k}}+\log \left(\mathrm{Obs}_{\mathrm{ijk}}\right)}$ \\
Site $_{\mathrm{j}} \sim \mathrm{N}\left(0, \sigma_{\text {site }}^{2}\right)$ \\
Time $_{\mathrm{k}} \sim \mathrm{N}\left(0, \sigma_{\text {time }}^{2}\right)$ \\
\hline
\end{tabular}

where Visits $i_{i j k}$ is the number of bee visits observed in the $i$ th transect in site $j$ during time period $k$, and $\mathrm{Obs}_{i j k}$ is the length of the observation time in the $i$ th transect in site $j$ during time period $k$. All of the following models included the same random intercept terms and offset but differed from equation (3) in the fixed effects included. The model for $\mathrm{H} 1$ was of the form

\begin{tabular}{l}
\hline Visits $_{\mathrm{ijk}}=\mathrm{T}_{\mathrm{ijk}}+$ Site $_{\mathrm{j}}+$ Time $_{\mathrm{k}}+\log \left(\mathrm{Obs}_{\mathrm{ijk}}\right) \quad(4)$ \\
\hline
\end{tabular}

where $\mathrm{T}_{i j k}$ is the transect $\mathrm{FR}$ volume (cube-root transformed) within the $i$ th transect in site $j$ during time 
period $k$; i.e., this model includes a term for local but not landscape-level FR. The model for H2a and H2b, which also includes landscape-level FR, was of the form

$$
\overline{\text { Visits }_{\mathrm{ijk}}=\mathrm{T}_{\mathrm{ijk}}+\mathrm{L}_{\mathrm{ijk}}+\text { Site }_{\mathrm{j}}+\text { Time }_{\mathrm{k}}+\log \left(\mathrm{Obs}_{\mathrm{ijk}}\right) \quad(5)}
$$

where $\mathrm{L}_{i j k}$ is the landscape $\mathrm{FR}$ volume (cube-root transformed) within either a 250,500 , or $750 \mathrm{~m}$ radius (each spatial scale was run in separate models) surrounding the $i$ th transect in site $j$ during time period $k$ ; models were run both including and excluding the $\mathrm{T}_{i j k}$ term. The model for H3a was of the form

$$
\begin{aligned}
& \text { Visits }_{\mathrm{ijk}}=\mathrm{T}_{\mathrm{ijk}}+\mathrm{L}_{\mathrm{ij}(1)}+\sum_{\mathrm{k}=1}^{\mathrm{k}} \mathrm{L}_{\mathrm{ijk}}+\mathrm{Site}_{\mathrm{j}}+\mathrm{Time}_{\mathrm{k}}+\log \left(\mathrm{Obs}_{\mathrm{ijk}}\right) \\
& \mathrm{L}_{\mathrm{ijk}}=\left(\mathrm{L}_{\mathrm{ijk}} \geq \mathrm{L}_{\mathrm{ij}(\mathrm{k} 1)} \rightarrow 0\right) \bigwedge\left(\mathrm{L}_{\mathrm{ijk}}<\mathrm{L}_{\mathrm{ij}(\mathrm{k} 1)} \rightarrow \mathrm{L}_{\mathrm{ijk}} \mathrm{L}_{\mathrm{ij}(\mathrm{k} 1)}\right)
\end{aligned}
$$

where $\mathrm{L}_{i j(1)}$ is the landscape $\mathrm{FR}$ volume (cube-root transformed) within either a 250,500 , or $750 \mathrm{~m}$ radius (each spatial scale was run in separate models) surrounding the $i$ th transect in site $j$ during the first time period (1) that bees were observed visiting flowers, and $\Delta \mathrm{L}_{i j k}$ is the non-positive change (positive changes were equivalent to no change, i.e. equalling zero) in the landscape FR volume (cube-root transformed), within the same radius as the $\mathrm{L}_{i j}(1)$ term, surrounding the $i$ th transect in site $j$ from the previous time period $(k-1)$ to the current time period $k$, from which was calculated the cumulative sum of $\Delta \mathrm{L}_{i j k}$ across all time periods since bees were first observed visiting flowers; models were run both including and excluding the $\mathrm{T}_{i j k}$ term. Finally, the model for H3b was of the form

$\overline{\text { Visits }_{\mathrm{ijk}}=\mathrm{T}_{\mathrm{ijk}}+\sum_{\mathrm{k}=1}^{\mathrm{k}} \mathrm{L}_{\mathrm{ijk}}+\text { Site }_{\mathrm{j}}+\mathrm{Time}_{\mathrm{k}}+\log \left(\mathrm{Obs}_{\mathrm{ijk}}\right) \quad(7)}$

where the cumulative sum of $\mathrm{L}_{i j k}$ was calculated across all time periods since bees first were observed visiting flowers (including the present time period) and was run both including and excluding the $\mathrm{T}_{i j k}$ term. Models for H3b were only run for bee genera that might produce multiple broods per season (Augochlorella, Bombus , Halictus ,Lasioglossum; Packer et al. 2007).

Model selection with the MuMIn package (Bartoń 2019) was used to determine which models best predicted bee visits, considering all models with $\Delta \mathrm{AICc}<2$. Model selection was run in two iterations, with unknown land area assigned either the median FR value calculated from all land types within a specific radius during a given time period ('median models'), or the minimum FR value calculated from all land types within a specific radius during a given time period, which was always zero ('minimum models'). This was done to test the sensitivity of our conclusions to the presence of unknown areas; we found no differences between the identities of models with $\triangle \mathrm{AICc}<2$ when unknown areas were assigned either minimum or median FR values, and we have presented the results from both iterations.

\section{Results}

Floral resources

Floral volume was the best predictor of both daily nectar sugar mass $\left(\mu \mathrm{g} /\right.$ day; $\mathrm{R}^{2}=0.39, \mathrm{p}=3.6 \times 10^{-6}$, $\mathrm{n}=46$, Fig. 2a), and pollen volume ( $\mu \mathrm{l} /$ flower; $\mathrm{R}^{2}=0.40, \mathrm{p}=6.0 \times 10^{-5}, \mathrm{n}=33$, Fig. $2 \mathrm{~b}$ ), and therefore was used to represent FR in all subsequent analyses. Flower length, width, height, and surface area were also significantly correlated with nectar and pollen volume, but to a lesser degree $\left(\mathrm{R}^{2}[?]\right.$ 0.34). Floral measurements, pollen volumes, and nectar sugar mass for individual species can be found in Appendix, Table A2-A4.

Across many of the landscapes sampled in this study, there was a high degree of correlation between the FR at each spatial scale within a given time period, particularly between the $500 \mathrm{~m}$ and $750 \mathrm{~m}$ spatial scales 
(Fig. 3). In most landscapes, the fourth (last) time period had the lowest FR, and the highest FR abundance generally was seen in either in the second or third time period, with a few landscapes having the highest FR of the season in the first time period (Fig. 3).

Most common bee genera

Over the season, 8422 bee visits were observed across all sites, with 1647 visits observed in the first time period, 1946 in the second, 2211 in the third, and 2618 in the fourth. Bees in the genera Andrena(mining bees), Apis (A. mellifera ; Western honey bee),Bombus (bumble bees), Halictus (furrow bees), andLasioglossum (sweat bees) were observed visiting flowers in at least four of the 27 sites surveyed during all time periods. Bees in the genus Augochlorella (A. aurata ; golden green sweat bee) were observed during just the first and second time periods in at least four sites, while Megachile (leafcutter bees) were observed in the second and third, and Peponapis (P. pruinosa; hoary squash bee) in the third and fourth. All other bee genera found in at least four sites were only observed during one time period.

H1: Bee visits are only influenced by local FR

No models for any genera supported the hypothesis that bee visits were influenced only by local FR (Table 1). Several taxa did, however, show a positive relationship with the abundance of FR within transects based on the best models which also included landscape FR abundance as a predictor (Table 1; Fig, 4 for Halictus and Peponapis ).

H2: Bee visits are influenced by the present abundance of landscape FR

The number of visits observed from Andrena, Augochlorella ,Megachile, and Peponapis supported hypothesis $\mathrm{H} 2 \mathrm{~b}$, that bee visits were negatively associated with the present abundance of landscape FR (Fig. 4; Table 1). The number of bee visits was best predicted by models of present landscape FR at a $250 \mathrm{~m}$ scale forMegachile $(\Delta \mathrm{AICc}=0)$, and at a $750 \mathrm{~m}$ scale for Augochlorella $(\Delta \mathrm{AICc}=0)$ and Peponapis $(\Delta \mathrm{AICc}=$ 0 ).Andrena visits were best predicted by models of the present landscape FR at a $250 \mathrm{~m}$ scale ( $\Delta$ AICc [?] 1.00) but showed some support for hypothesis H3a (Table 1), described in the following section.

H3: Bee visits are influenced by the previous abundance of landscape FR

For Halictus and Lasioglossum, hypothesis H3a - that bee visits were influenced by the previous abundance of landscape FR within a season - was best supported (Table 1; Fig. 4). Halictus andLasioglossum visits were best predicted from models including landscape FR abundance during the first time period, and the non-positive change in the abundance of landscape FR since the first time period within $750 \mathrm{~m}$ of sampling locations (both $\triangle \mathrm{AICc}=0$ ). For both genera, bee visits were negatively associated with landscape FR during the first time period and were also lower in landscapes that experienced greater decreases in landscape FR over the season (Table 1; Fig. 4). Andrena visits also showed some support for hypothesis H3a, with bee visits predicted by the previous abundance of landscape FR at the $250 \mathrm{~m}$ scale ( $\Delta$ AICc [?] 1.81), but in this genus, greater decreases in FR over the season were associated with a higher number of bee visits. However, hypothesis H2b had slightly better support inAndrena (Table 1), as described in the previous section.

Bombus visitation rates best supported hypothesis $\mathrm{H} 3 \mathrm{~b}$, that bee visits are influenced by the cumulative abundance of landscape FR since the first time period (Table 1; Fig 4). Landscape FR was a predictor ofBombus visits at all spatial scales over which it was measured, but the $250 \mathrm{~m}$ scale was the strongest predictor $(\triangle \mathrm{AICc}=0)$. Visits fromBombus were positively associated with the cumulative abundance of landscape FR at all spatial scales.

\section{Discussion}

We found that FR in the landscape over preceding months was an important predictor of bee activity for most bees that were foraging over the entire season. High FR abundance in previous months was positively related to the number of visits for bees that were more social and produced multiple broods per season (Bombus ), while stable FR abundance over previous months positively influenced the number of visits for genera that were less social and produced fewer broods per season (Halictus and Lasioglossum ). For all other 
bees, including solitary bees (Andrena, Megachile, and Peponapis ) and bees with shorter observed foraging periods (Augochlorella, Megachile, and Peponapis ), the present abundance of FR in the landscape was the best predictor of bee visits. However, the present abundance of FR was negatively related to local bee visits, possibly because of a dilution of pollinators across high-FR landscapes. Individual bee taxa exhibit unique combinations of foraging distances, foraging periods, and numbers of brood produced per season, all of which can influence how bees respond to changes in landscape FR abundance over a season. Our research acknowledged these taxonomic differences by assuming each bee genus observed would respond at different spatial and temporal scales to the abundance of FR in a landscape. By doing this, we were able to document important differences in the ways in which each genus was influenced by the spatial and temporal availability of FR.

Much of the previous research on wild bees responding to FR in agricultural landscapes has found that a higher abundance of FR is associated with larger populations, higher densities, or greater numbers of visits (Mandelik et al. 2012, Kovács-Hostyánszki et al. 2013, Mallinger et al. 2016, Martins et al. 2018). In our study, the number of visits by Bombus was positively related to cumulative landscape FR, in line with the hypothesis that bees producing multiple broods in a season can increase population sizes within one season with access to more FR through time. This finding agrees with previous research examining B. vosnesenskii colony responses to FR in agricultural landscapes, which found that the production of males and workers was more positively related to high early-season FR abundance in the surrounding landscape than to late-season FR (Williams et al. 2012). Bumble bees represent some of the most common and important pollinators for both wildflowers and crops in the Northern Hemisphere, but many species are facing declines (Goulson et al. 2008). Our results suggest that early-season FR in agricultural landscapes could promote high bumble bee visitation rates later in the season, and potentially maintain or increase colony sizes over a season.

For Halictus and Lasioglossum, our findings best supported the hypothesis that these bees were producing a single brood per season, and therefore were able to maintain (but not increase) their population sizes when FR was consistent or increased over time. However, in the region this study was conducted, both Halictus andLasioglossum include eusocial species that produce multiple broods per season and solitary species that only produce a single brood (Mitchell 1960, Packer et al. 2007). Given the stronger support for the hypothesis that these genera responded as expected for single-brood-producing bees, our results indicate either that more solitary species were present in our study locations, or that the more social species in this region were producing too few brood per season to exhibit a strong response to the cumulative abundance of FR. Geographic variations can influence both the degree of sociality and the number of broods produced within single species of Halictus andLasioglossum, with a general pattern of more solitary bees and fewer broods being produced at higher elevations and latitudes (Richards and Packer 1995, Wcislo 1997, Davison and Field 2016). In our study locations, most Halictus and Lasioglossum species are closer to their northern range limit (Mitchell 1960), which should increase the prevalence of populations in this region that produce fewer broods per season and exhibit less social behaviours.

The remaining bee genera (Andrena, Augochlorella, Megachile, and Peponapis ) were all most influenced by the present abundance of FR in the landscape. These genera include both eusocial (Augochlorella) and solitary bees (Andrena, Megachile, and Peponapis ). Although Augochlorellavisits were primarily observed during the first and second sampling periods, the only species of Augochlorella in eastern Canada, $A$. aurata (Packer et al. 2007), is in flight for the entire growing season (Mitchell 1960). Similar to Halictus and Lasioglossum, some A. aurata populations are solitary, while others produce just two broods (one worker and one reproductive brood) per season (Packer et al. 1989). If only two broods were produced over the entire season by $A$. aurata populations, we might have been unable to observe any influence of cumulative FR abundance by the second time period (only the first and second time periods were analyzed for this genus). The fact that visits from the solitary bee generaAndrena, Megachile, and Peponapis were apparently unaffected by past FR makes sense in light of the short flight periods of individual species within these genera. Although Andrena were found foraging over the entire season, this genus comprises 75 species in eastern Canada (Packer et al. 2007), many of which are active as adults for just one or two months (LaBerge 1986, Larkin et al. 2008). Megachile were observed foraging during the second, third, and fourth time periods, but 
a number of the species in this region have more restricted foraging periods (Mitchell 1962, Sheffield et al. 2011). The single local species of Peponapis , P. pruinosa, is a specialist on pollen in the Cucurbitaceae family and has a foraging period synchronized with its flowering in southern Ontario (Willis and Kevan 1995). Given the prevalence of species with short flight periods in our study area, the foraging periods of many individual species were likely too short to respond to fluctuations in FR at the roughly monthly scale we considered. Future research should focus on examining how fluctuations in FR over shorter temporal scales (e.g., weekly) influence bee activity, which would allow for development of agricultural landscapes that specifically benefit those species with short flight periods.

Despite the variety of life-history traits represented by Andrena, Augochlorella, Megachile, andPeponapis , all four genera responded similarly to the present abundance of FR; visits were generally fewer in landscapes that had a high abundance of FR. Several studies have previously found that abundant FR can decrease bee density on crops, either through dilution of pollinators across a landscape (Kovács-Hostyánszki et al. 2013, Holzschuh et al. 2016), or through distraction of pollinators from crops to other resource-rich areas (Lander et al. 2011, Nicholson et al. 2019). This may indicate that the landscapes used in our study generally provided a high amount of FR outside the local sampling areas, perhaps because we selected sampling locations based on their proximity to farms growing fruit or vegetables. Population sizes for solitary bees that produce a single brood per season (Andrena, Megachile, andPeponapis ) should also be strongly limited by the amount of FR available in the previous year, which would be used to produce the generation foraging in the current year. Since we did not know the relative abundance of FR in the previous year, this may have been the primary factor limiting bee populations, especially for species that only forage for a few weeks in a season.

Differences in body size can contribute to differences in the maximum foraging ranges of bee taxa (Greenleaf et al. 2007) and thus to availability of FR to bees within the landscape surrounding sampling locations. For most genera, we found that the number of bee visits observed within a transect was best predicted by landscape FR at a consistent spatial scale. Within genera like Andrena ,Halictus, and Lasioglossum, individual species can vary greatly in body size (Mitchell 1960), but the average body size across a genus did not seem to correlate with the spatial scale at which landscape FR was most relevant. Visits for Andrena , a relatively small-bodied bee (body length ranges from 4-15 mm; Mitchell 1960) were best predicted by $\mathrm{FR}$ at $250 \mathrm{~m}$, the smallest spatial scale we measured, while visits from other small-bodied bees like Augochlorella (average body length of A. aurata is $5.25 \mathrm{~mm}$; Mitchell 1960),Halictus (body length 7-13 mm; Mitchell 1960) andLasioglossum (body length 3.5-10 mm; Mitchell 1960) were best predicted by FR at 750 $\mathrm{m}$, the largest spatial scale measured. On the other hand, visits from the relatively large-bodied Bombus (body length 5-28 mm; Laverty and Harder 1988) and Megachile (body length 6-25 mm; Sheffield et al. 2011) were best predicted by the abundance of FR within just $250 \mathrm{~m}$ around a sampling location. The spatial arrangement of both FR and nesting habitat in a landscape are likely the more relevant predictors of how far most bees are actually foraging (Zurbuchen et al. 2010). The spatial scales we have determined as the best predictor of bee visits may therefore represent the upper end of foraging areas used by bees in the majority of landscapes that we examined, with many bees actually foraging in smaller areas of landscapes with more densely packed resources.

By teasing apart the responses of individual genera, we discovered a diversity of responses among taxonomic groups, highlighting potential problems with lumping all non-Bombus bees into a single functional group, or with examining responses of the entire bee community to FR. Our research highlights the importanceparticularly for social taxa - of not only the current floral resource landscape but also the FR present earlier in the season. This information can help determine how to configure agricultural landscapes in a way that promotes bee population persistence and growth, and thus, increases the pollination services crops receive. Our findings suggest that bees with longer flight periods likely benefit from continuous, consistent provision of FR throughout a single season, and high FR abundance early in the season. However, the number of bee visits observed may not be a good proxy for bee population sizes. An important next step will be to determine how across-year patterns in visitation rates change with spatiotemporal fluctuations in FR, particularly for single-brood species which can only respond positively to FR availability over this timescale. Though we observed fewer visits by bees with short foraging periods in landscapes with a high present abundance of FR, 
this pattern should not hold across years: if other factors are not limiting, more abundant floral resources in landscapes should yield higher bee abundances in subsequent years.

\section{Acknowledgements}

Thank you to Lenore Fahrig for providing the GPS unit; to Joseph Bennett, Lenore Fahrig, Jeremy Kerr, and Risa Sargent for their input on early drafts; and to Katie Baillie-David, Alexander Hare, and Megan McAulay for assistance in the field and lab. This work was funded by the University of Ottawa and an Ontario Graduate Scholarship to JG.

\section{Conflict of Interest}

None declared.

\section{Data Accessibility Statement}

Data for this study will be archived in Dryad upon acceptance.

\section{Author Contributions}

JG and JF originally formulated the idea and developed methodology. JG conducted fieldwork and analyzed the data. JG wrote the manuscript; JF provided editorial advice.

\section{References}

Ahrent, D. K., and C. E. Caviness. 1994. Natural Cross-Pollination of Twelve Soybean Cultivars in Arkansas. Crop Science 34:376-378.

Alarcon, R., N. M. Waser, and J. Ollerton. 2008. Year-to-year variation in the topology of a plant-pollinator interaction network. Oikos 117:1796-1807.

Arnold, R. M. 1982. Pollination, predation and seed set in Linaria vulgaris (Scrophulariaceae). American Midland Naturalist 107:360.

Ashman, T.-L., and M. S. Hitchens. 2000, May 23. Dissecting the causes of variation in intra-floresence allocation in a sexually polymorphic species, Fragaria virginiana (Rosaceae). American Journal of Botany $87: 197-204$.

Bartoń, K. 2019. MuMIn: Multi-Model Inference. R package version 1.43.6.

Baude, M., W. E. Kunin, N. D. Boatman, S. Conyers, N. Davies, M. A. K. Gillespie, R. D. Morton, S. M. Smart, and J. Memmott. 2016. Historical nectar assessment reveals the fall and rise of floral resources in Britain. Nature 530:85-88.

Biesboer, D. D. 1975. Pollen morphology of the Aceraceae. Grana 15:19-27.

Brooks, M., K. Kristensen, K. van Benthem, A. Magnusson, C. Berg, A. Nielsen, H. Skaug, M. Maechler, and B. Bolker. 2017. glmmTMB balances speed and flexibility among packages for zero-inflated generalized linear mixed modeling. The R Journal 9:378-400.

Brosi, B. J., P. R. Armsworth, and G. C. Daily. 2008. Optimal design of agricultural landscapes for pollination services. Conservation Letters 1:27-36.

Cane, J. H. 2005. Bees, pollination, and the challenges of sprawl. Pages 109-124 in E. Johnson and M. Klemens, editors. Nature in fragments: the legacy of sprawl. Columbia University Press, New York.

Cavers, P. B., I. J. Bassett, and C. W. Crompton. 1980. The biology of Canadian weeds. 47. Plantago lanceolata L. Canadian Journal of Plant Science 60:1269-1282.

Cawoy, V., V. Deblauwe, B. Halbrecq, J. Ledent, J. Kinet, and A. Jacquemart. 2006. Morph differences and honeybee morph preference in the distylous species Fagopyrum esculentum Moench. International Journal of Plant Sciences 167:853-861. 
Cawoy, V., J.-F. Ledent, J.-M. Kinet, and A.-L. Jacquemart. 2009. Floral Biology of common buckwheat (Fagopyrum esculentum Moench). The European Journal of Plant Science and Biotechnology 3:1-9.

Chmielewski, J. G., and J. C. Semple. 2001. The biology of Canadian weeds. 113. Symphyotrichum lanceolatum (Willd.) Nesom [Aster lanceolatus Willd.] and S. lateriflorum (L.) Löve \& Löve [Aster lateriflorus (L.) Britt.]. Canadian Journal of Plant Science 81:829-849.

Crone, E. E., and N. M. Williams. 2016. Bumble bee colony dynamics: quantifying the importance of land use and floral resources for colony growth and queen production. Ecology Letters 19:460-468.

Cruden, R. W. 1977. Pollen-ovule ratios: a conservative indicator of breeding systems in flowering plants. Evolution 31:32-46.

Cruden, R. W., and K. G. Jensen. 1979. Viscin threads, pollination efficiency and low pollen-ovule ratios. American Journal of Botany 66:875-879.

Van Damme, J. M. M. 1984. Gynodioecy in Plantago lanceolata L. III. Sexual reproduction and the maintenance of male steriles. Heredity 52:77-93.

Davison, P. J., and J. Field. 2016. Social polymorphism in the sweat beeLasioglossum (Evylaeus ) calceatum . Insectes Sociaux 63:327-338.

Erickson, E. H., G. A. Berger, J. G. Shannon, and J. M. Robins. 1978. Honey bee pollination increases soybean yields in the Mississippi Delta Region of Arkansas and Missouri. Journal of Economic Entomology 71:601-603.

Le Feon, V., F. Burel, R. Chifflet, M. Henry, A. R. Vaissiere, B. E. Vaissiere, and J. Baudry. 2013. Solitary bee abundance and species richness in dynamic agricultural landscapes. Agriculture, Ecosystems and Environment 166:94-101.

Gibson, R. H., B. Knott, T. Eberlein, and J. Memmott. 2011. Sampling method influences the structure of plant-pollinator networks. Oikos 120:822-831.

Goulson, D., G. C. Lye, and B. Darvill. 2008. Decline and conservation of bumble bees. Annual Review of Entomology 53:191-208.

Greenleaf, S. S., N. M. Williams, R. Winfree, and C. Kremen. 2007. Bee foraging ranges and their relationship to body size. Oecologia 153:589-596.

Hall, I. V., E. Steiner, P. Threadgill, and R. W. Jones. 1988. The biology of Canadian weeds. 84. Oenothera biennis L. Canadian Journal of Plant Science 68:163-173.

Harder, L. D. 1985. Morphology as a predictor of flower choice by bumble bees. Ecology 66:198-210.

Harder, L. D., J. D. Thomson, M. B. Cruzan, and R. S. Unnasch. 1985. Sexual reproduction and variation in floral morphology in an ephemeral vernal lily, Erythronium americanum. Oecologia 67:286-291.

Hebda, R. J., C. C. Chinnappa, and B. M. Smith. 1988. Pollen morphology of the Rosaceae of western Canada. II. Dryas , Fragaria ,Holodiscus . Canadian Journal of Botany 66:595-612.

Heinrich, B. 1976. Resource partitioning among some eusocial insects: Bumblebees. Ecology 57:874-889.

Hicks, D. M., P. Ouvrard, K. C. R. Baldock, M. Baude, M. A. Goddard, W. E. Kunin, N. Mitschunas, J. Memmott, H. Morse, M. Nikolitsi, L. M. Osgathorpe, S. G. Potts, K. M. Robertson, A. V. Scott, F. Sinclair, D. B. Westbury, and G. N. Stone. 2016. Food for pollinators: Quantifying the nectar and pollen resources of urban flower meadows. PLoS ONE 11:1-37.

Holl, K. D. 1995. Nectar resources and their influence on butterfly communities on reclaimed coal surface mines. Restoration Ecology 3:76-85. 
Holzschuh, A., M. Dainese, J. P. Gonzalez-Varo, S. Mudri-Stojnić, V. Riedinger, M. Rundlöf, J. Scheper, J. B. Wickens, V. J. Wickens, R. Bommarco, D. Kleijn, S. G. Potts, S. P. M. Roberts, H. G. Smith, M. Vilà, A. Vujić, and I. Steffan-Dewenter. 2016. Mass-flowering crops dilute pollinator abundance in agricultural landscapes across Europe. Ecology letters 19:1228-1236.

Hurd, P. D., E. G. Linsley, and A. E. Michelbacher. 1974. Ecology of the squash and gourd bee, Peponapis pruinosa, on cultivated cucurbits in California (Hymenoptera: Apoidea). Smithsonian Contributions to Zoology:1-17.

Hutchings, M. J., and E. A. C. Price. 1999. Glechoma hederacea L. (Nepeta glechoma Benth., N. hederacea (L.) Trev.). Journal of Ecology 87:347-364.

Idris, A. B., and E. Grafius. 1995. Wildflowers as nectar sources forDiadegma insulare (Hymenoptera: Ichneumonidae), a parasitoid of Diamondback Moth (Lepidoptera: Yponomeutidae). Environmental Entomology 24:1726-1735.

Kang, H. S., B. P. Rihard, and C. Nam-Kee. 1991. Seasonal changes in sexual allocation within flowers of Chelidonium majus(Papaveraceae). The Korean Journal of Ecology 14:415-433.

Kennedy, C. M., E. Lonsdorf, M. C. Neel, N. M. Williams, T. H. Ricketts, R. Winfree, R. Bommarco, C. Brittain, A. L. Burley, D. Cariveau, L. G. Carvalheiro, N. P. Chacoff, S. A. Cunningham, B. N. Danforth, J.-H. Dudenhöffer, E. Elle, H. R. Gaines, L. A. Garibaldi, C. Gratton, A. Holzschuh, R. Isaacs, S. K. Javorek, S. Jha, A. M. Klein, K. Krewenka, Y. Mandelik, M. M. Mayfield, L. Morandin, L. A. Neame, M. Otieno, M. Park, S. G. Potts, M. Rundlöf, A. Saez, I. Steffan-Dewenter, H. Taki, B. F. Viana, C. Westphal, J. K. Wilson, S. S. Greenleaf, and C. Kremen. 2013. A global quantitative synthesis of local and landscape effects on wild bee pollinators in agroecosystems. Ecology Letters 16:584-599.

Kosenko, V. N. 1999. Contributions to the pollen morphology and taxonomy of the Liliaceae. Grana 38:20-30.

Kouonon, L. C., A.-L. Jacquemart, A. I. Zoro Bi, P. Bertin, J.-P. Baudoin, and Y. Dje. 2009. Reproductive biology of the andromonoecious Cucumis melo subsp. agrestis (Cucurbitaceae). Annals of Botany 104:11291139 .

Kovács-Hostyánszki, A., S. Haenke, P. Batáry, B. Jauker, A. Báldi, T. Tscharntke, and A. Holzschuh. 2013. Contrasting effects of mass-flowering crops on bee pollination of hedge plants at different spatial and temporal scales. Ecological Applications 23:1938-1946.

Kremen, C., N. M. Williams, and R. W. Thorp. 2002. Crop pollination from native bees at risk from agricultural intensification. Proceedings of the National Academy of Sciences 99:16812-16816.

LaBerge, W. E. 1986. The zoogeography of Andrena Fabricius (Hymenoptera: Andrenidae) of the Western Hemisphere. Pages 110-115 Proceedings of the Ninth North American Prairie Conference.

Lander, T. A., D. P. Bebber, C. T. L. Choy, S. A. Harris, and D. H. Boshier. 2011. The circe principle explains how resource-rich land can waylay pollinators in fragmented landscapes. Current Biology 21:1302-1307.

Larkin, L. L., J. L. Neff, and B. B. Simpson. 2008. The evolution of a pollen diet: Host choice and diet breadth of Andrena bees (Hymenoptera: Andrenidae). Apidologie 39:133-145.

Lau, P., V. Bryant, J. D. Ellis, Z. Y. Huang, J. Sullivan, D. R. Schmehl, A. R. Cabrera, and J. Rangel. 2019. Seasonal variation of pollen collected by honey bees (Apis mellifera) in developed areas across four regions in the United States. PLoS ONE 14.

Laverty, T. M., and L. D. Harder. 1988. The bumble bees of eastern Canada. The Canadian Entomologist 120:965-987.

Lemna, W. K., and C. G. Messersmith. 1990. The biology of Canadian weeds. 94. Sonchus arvensis L. Canadian Journal of Plant Science 70:509-532. 
Mallinger, R. E., J. Gibbs, and C. Gratton. 2016. Diverse landscapes have a higher abundance and species richness of spring wild bees by providing complementary floral resources over bees' foraging periods. Landscape Ecology 31:1523-1535.

Mandelik, Y., R. Winfree, T. Neeson, and C. Kremen. 2012. Complementary habitat use by wild bees in agro-natural landscapes. Ecological Applications 22:1535-1546.

Martins, K. T., C. H. Albert, M. J. Lechowicz, and A. Gonzalez. 2018. Complementary crops and landscape features sustain wild bee communities. Ecological Applications 28:1093-1105.

Matteson, K. C., J. S. Ascher, and G. A. Langellotto. 2008. Bee Richness and Abundance in New York City Urban Gardens. Annals of the Entomological Society of America 101:140-150.

Memmott, J. 1999. The structure of a plant-pollinator food web. Ecology Letters 2:276-280.

Mitchell, T. B. 1960. Bees of the eastern United States. I. Technical bulletin (North Carolina Agricultural Experiment Station) 141:1-538.

Mitchell, T. B. 1962. Bees of the eastern United States. II. Technical bulletin (North Carolina Agricultural Experiment Station) 152:1-557.

Moon, H.-K., S. Vinckier, E. Smets, and S. Huysmans. 2008. Comparative pollen morphology and ultrastructure of Mentheae subtribe Nepetinae (Lamiaceae). Review of Palaeobotany and Palynology 149:174-186.

Müller, A., S. Diener, S. Schnyder, K. Stutz, C. Sedivy, and S. Dorn. 2006. Quantitative pollen requirements of solitary bees: Implications for bee conservation and the evolution of bee-flower relationships. Biological Conservation 130:604-615.

Murray, T. E., M. Kuhlmann, and S. G. Potts. 2009. Conservation ecology of bees: populations, species and communities. Apidologie 40:211-236.

Nave, A., F. Gonçalves, A. L. Crespí, M. Campos, and L. Torres. 2016. Evaluation of native plant flower characteristics for conservation biological control of Prays oleae. Bulletin of Entomological Research 106:249257.

Nepi, M., and E. Pacini. 1993. Pollination, pollen viability and pistil receptivity in Cucurbita pepo . Annals of Botany 72:527-536.

Nicholson, C. C., T. H. Ricketts, I. Koh, H. G. Smith, E. V. Lonsdorf, and O. Olsson. 2019. Flowering resources distract pollinators from crops: Model predictions from landscape simulations. Journal of Applied Ecology 56:618-628.

Ogilvie, J. E., and J. R. Forrest. 2017. Interactions between bee foraging and floral resource phenology shape bee populations and communities. Current Opinion in Insect Science 21:75-82.

Olsson, U. 1974. A biometric study of the pollen morphology ofLinaria vulgaris (L.) Miller and L. repens (L.) Miller (Schrophulariaceae) and their hybrid progeny in F1 and F2 generations. Grana 14:92-99.

Packer, L., J. A. Genaro, and C. S. Sheffield. 2007. The bee genera of eastern Canada. Canadian Journal of Arthropod Identification 3:1-32.

Packer, L., V. Jessome, C. Lockerbie, and B. Sampson. 1989. The phenology and social biology of four sweat bees in a marginal environment: Cape Breton Island. Canadian Journal of Zoology 67:2871-2877.

Paradis, E., J. Claude, and K. Strimmer. 2004. APE: Analyses of Phylogenetics and Evolution in R language. Bioinformatics 20:289-290.

Pellmyr, O. 1985. The pollination biology of Actaea pachypoda and A. rubra (Including A. erythrocarpa) in northern Michigan and Finland. Bulletin of the Torrey Botanical Club 112:265. 
Perveen, A., and M. Qaiser. 2008. Pollen flora of Pakistan-LVI. Cucurbitaceae. Pakistan Journal of Botany 40:9-16.

R Core Team. 2019. R: A language and environment for statistical computing. R Foundation for Statistical Computing, Vienna, Austria.

Richards, M. H., and L. Packer. 1995. Annual variation in survival and reproduction of the primitively eusocial sweat bee Halictus ligatus (Hymenoptera: Halictidae). Canadian Journal of Zoology 73:933-941.

Roulston, T. H., J. H. Cane, and S. L. Buchmann. 2000. What governs protein content of pollen: Pollinator preferences, pollen-pistil interactions, or phylogeny? Ecological Monographs 70:617.

Roulston, T. H., and K. Goodell. 2011. The role of resources and risks in regulating wild bee populations. Annual Review of Entomology 56:293-312.

Rundlöf, M., A. S. Persson, H. G. Smith, and R. Bommarco. 2014. Late-season mass-flowering red clover increases bumble bee queen and male densities. Biological Conservation 172:138-145.

Schultz, C. B., and K. M. Dlugosch. 1999. Nectar and hostplant scarcity limit populations of an endangered Oregon butterfly. Oecologia 119:231-238.

Sheffield, C. S., C. Ratti, L. Packer, and T. Griswold. 2011. Leafcutter and mason bees of the genus Megachile Latreille (Hymenoptera: Megachilidae) in Canada and Alaska. Canadian Journal of Arthropod Identification 18:1-107.

Sivinski, J., D. Wahl, T. Holler, S. Al Dobai, and R. Sivinski. 2011. Conserving natural enemies with flowering plants: Estimating floral attractiveness to parasitic Hymenoptera and attraction's relationship to flower and plant morphology. Biological Control 58:208-214.

Steffan-Dewenter, I., U. Munzenberg, C. Burger, C. Thies, and T. Tscharntke. 2002. Scale-dependent effects of landscape context on three pollinator guilds. Ecology 83:1421.

Sullivan, J. R. 1983. Comparative reproductive biology of Acer pensylvanicum and A. spicatum (Aceraceae). American Journal of Botany 70:916-924.

Taha, E. A., and Y. A. Bayoumi. 2009. The value of honey bees (Apis mellifera, L.) as pollinators of summer seed watermelon (Citrullus lanatus colothynthoides L.) in Egypt. Acta Biologica Szegediensis 53:33-37.

Timberlake, T. P., I. P. Vaughan, and J. Memmott. 2019. Phenology of farmland floral resources reveals seasonal gaps in nectar availability for bumblebees. Journal of Applied Ecology 56:1365-2664.13403.

Vidal, M. das G., D. de Jong, H. C. Wien, and R. A. Morse. 2006. Nectar and pollen production in pumpkin (Cucurbita pepo L.). Revista Brasileira de Botânica 29.

Warwick, S. I., and R. D. Sweet. 1983. The biology of Canadian weeds. 58. Galinsoga parviflora and G. quadriradiata (= G. ciliata ). Canadian Journal of Plant Science 63:695-709.

Wcislo, W. T. 1997. Behavioral environments of sweat bees (Halictinae) in relation to variability in social organization. Pages 316-332in J. C. Choe and B. J. E. Crespi, editors. The Evolution of Social Behaviour in Insects and Arachnids. Cambridge University Press.

Westphal, C., I. Steffan-Dewenter, and T. Tscharntke. 2009. Mass flowering oilseed rape improves early colony growth but not sexual reproduction of bumblebees. Journal of Applied Ecology 46:187-193.

Williams, N. M., J. Regetz, and C. Kremen. 2012. Landscape-scale resources promote colony growth but not reproductive performance of bumble bees. Ecology 93:1049-1058.

Willis, D. S., and P. G. Kevan. 1995. Foraging dynamics of Peponapis pruinosa (Hymenoptera: Anthophoridae) on pumpkin (Cucurbita pepo ) in southern Ontario. The Canadian Entomologist 127:167-175. 
Winkler, K., F. L. Wäckers, L. V. Kaufman, V. Larraz, and J. C. van Lenteren. 2009. Nectar exploitation by herbivores and their parasitoids is a function of flower species and relative humidity. Biological Control 50:299-306.

Zurbuchen, A., L. Landert, J. Klaiber, A. Müller, S. Hein, and S. Dorn. 2010. Maximum foraging ranges in solitary bees: only few individuals have the capability to cover long foraging distances. Biological Conservation 143:669-676.

\section{Tables}

Table 1 Models of bee visits and corresponding hypotheses with the landscape scale within which FR were measured (radius in metres around a sampling location), where ' $\mathrm{FR}$ ' = floral resources, and hypotheses are as follows: ' $\mathrm{H}_{0}$ ' = bee visits are not limited by $\mathrm{FR}$; ' $\mathrm{H}_{1}$ ' = bee visits are limited only by the present abundance of local FR; ' $\mathrm{H}_{2 \mathrm{a}}$ ' = bee visits are best predicted by the present abundance of landscape FR, and will increase with increasing FR; ' $\mathrm{H}_{2 \mathrm{~b}}$ ' = bee visits are best predicted by the present abundance of landscape FR, and decrease with increasing $\mathrm{FR}$; ' $\mathrm{H}_{3 \mathrm{a}}$ ' $=$ bee visits are best predicted by the abundance of landscape $\mathrm{FR}$ when foraging is first observed and any non-positive changes in abundance in subsequent time periods; and ' $\mathrm{H}_{3 \mathrm{~b}}$ ' = bee visits are limited by the cumulative abundance of landscape FR from when foraging is first observed. Models shown are those with $\Delta$ AICc values $<2$ when all unknown areas in a spatial scale were assigned either the median ('Med') or minimum ('Min') volume of FR measured across all resource-providing land types during a given time period.

\begin{tabular}{llc}
\hline Hypotheses for bee visits and landscape scale of FR & Hypotheses for bee visits and landscape scale of FR & Hypotheses for \\
\hline \multirow{2}{*}{ Andrena } & H2b & $250 \mathrm{~m}$ \\
& H3a & $250 \mathrm{~m}$ \\
Augochlorella & H2b & $750 \mathrm{~m}$ \\
Bombus & H3b & $250 \mathrm{~m}$ \\
& H3b & $750 \mathrm{~m}$ \\
& H3b & $250 \mathrm{~m}$ \\
& H3b & $500 \mathrm{~m}$ \\
Halictus & H3b & $750 \mathrm{~m}$ \\
& H3a & $750 \mathrm{~m}$ \\
& & $250 \mathrm{~m}$ \\
Lasioglossum & H2a & $250 \mathrm{~m}$ \\
Megachile & H2a & $750 \mathrm{~m}$ \\
& H3a & $250 \mathrm{~m}$ \\
& H2b & $250 \mathrm{~m}$ \\
\hline
\end{tabular}

* All FR values input for this term were negative or 0 (non-positive change in FR), so a negative coefficient means that the number of visits were negatively related to smaller decreases in FR, while a positive coefficient means that the number of visits were positively related to smaller decreases in FR 
Figures 

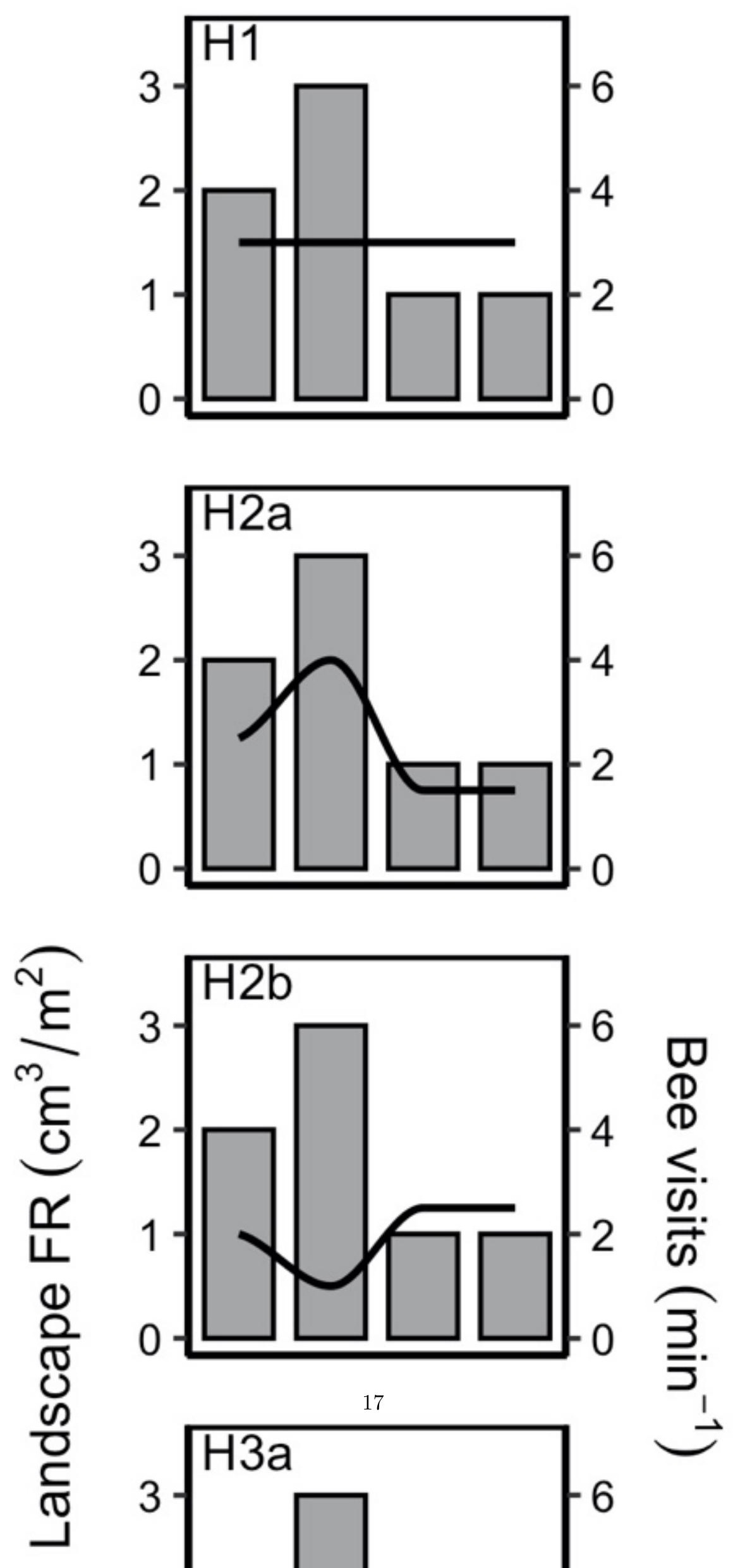
Fig. 1 Hypothetical responses of bee visits (in transects) to the amount of floral resources (FR) in the surrounding landscape in four time periods over one season, with FR represented as grey bars, and bee visits represented as black lines, with hypotheses depicted as follows: $\mathrm{H} 1$ = bee visits are not influenced by the abundance of landscape FR; H2a = bee visits are limited by the abundance of FR in the landscape during the present time period, and are higher in time periods with higher FR; H2b = bee visits are influenced by the abundance of FR in the landscape during the present time period, but are lower in time periods with high FR due to dilution of bees across the landscape; H3a = bee visits are limited by the abundance of FR in a landscape in the first time period (when foraging hypothetically begins), and by non-positive changes in $\mathrm{FR}$ abundance in subsequent time periods relative to the first time period; and $\mathrm{H} 3 \mathrm{~b}=$ bee visits in a given time period are limited by the cumulative abundance of landscape FR over all previous time periods, from when foraging began.
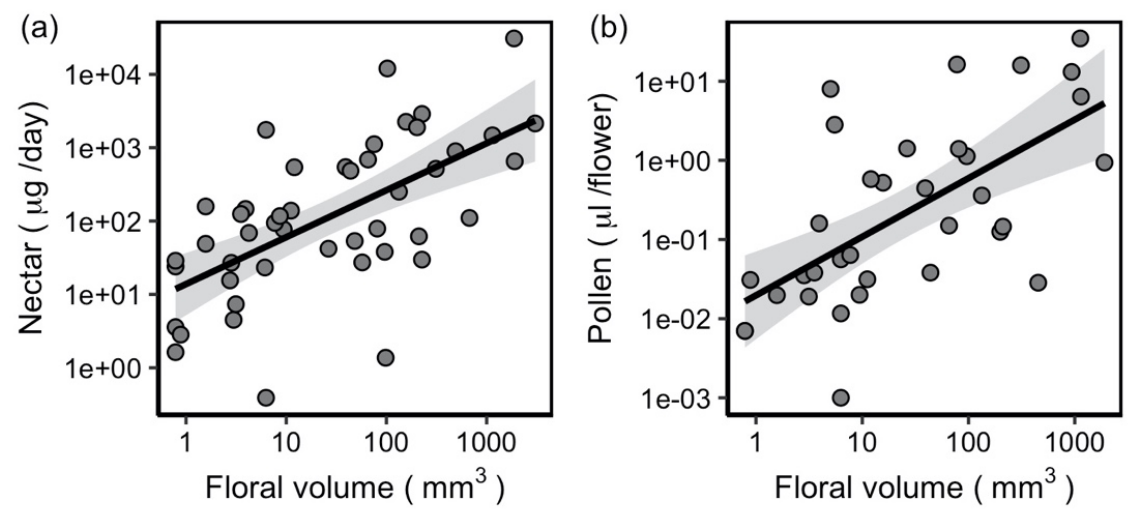

(c)

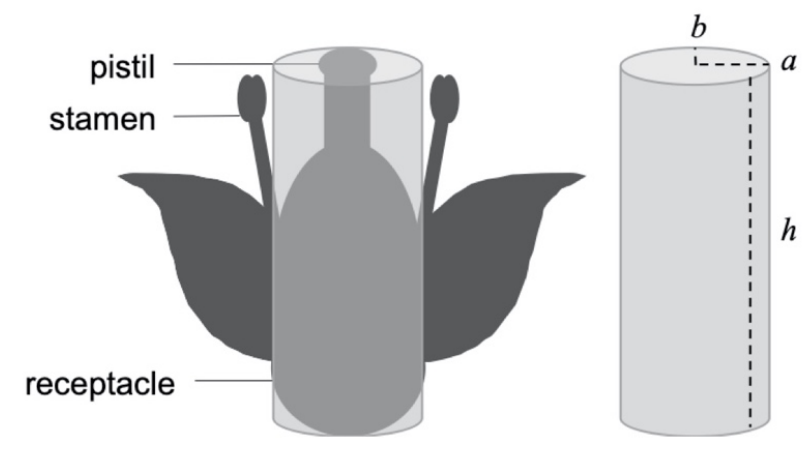

Fig. 2 Correlations between floral volume and (a) daily nectar sugar mass in 46 flowering species, and (b) pollen volume in 33 flowering species; with (c) a diagram of floral volume measurements using the volume of an elliptic cylinder $(\mathrm{V}=\pi \mathrm{abh})$. Black lines in (a) and (b) represent linear model estimates of nectar mass or pollen volume by floral volume; shaded areas are $95 \%$ confidence intervals. Note logarithmic axes. 
Spatial scale $\quad \begin{array}{llllll}250 & \circ & 500 & \circ & 750\end{array}$
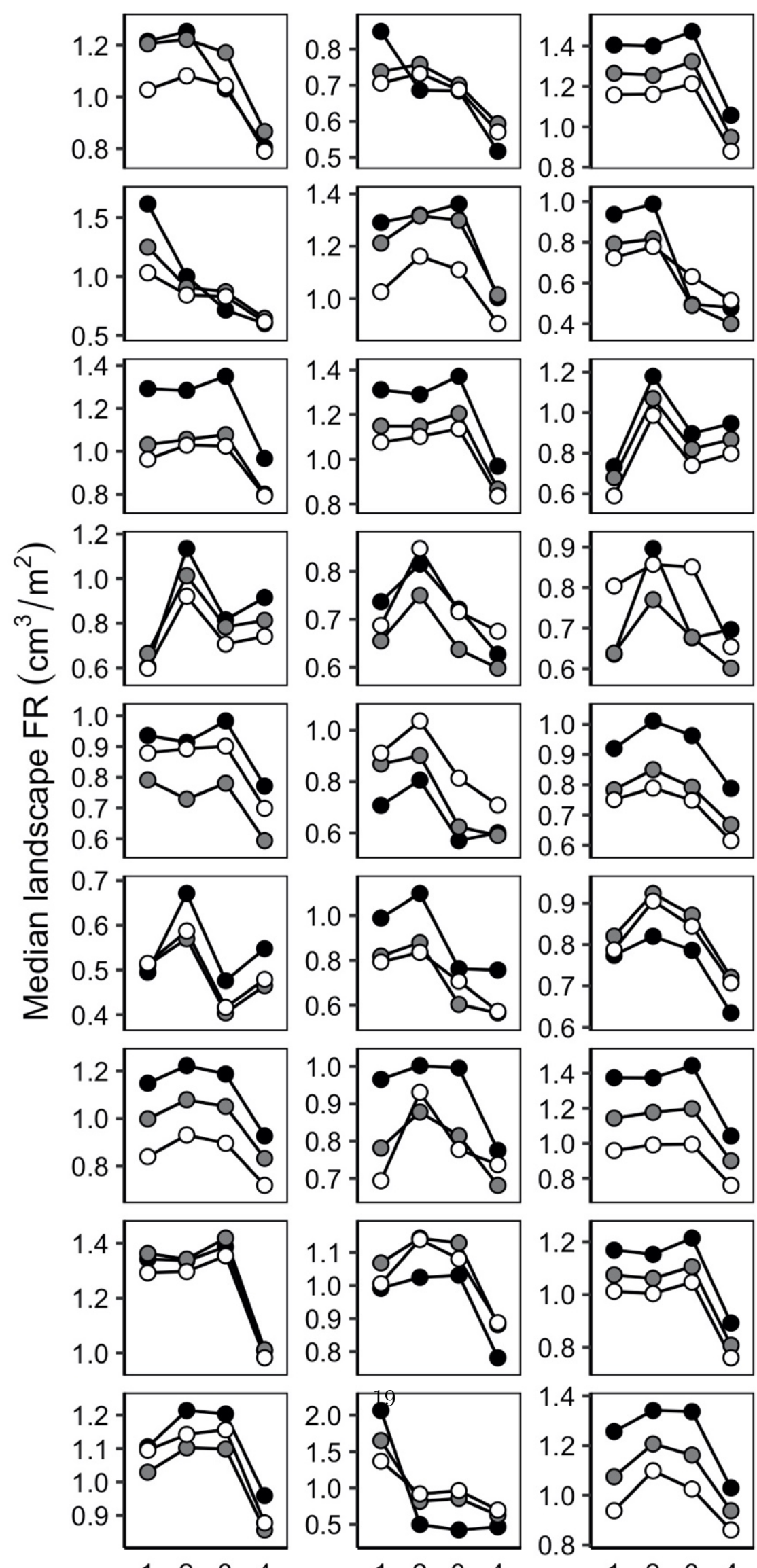
Fig. 3 Median volumes of floral resources ('FR') per square metre within each landscape spatial scale (250 $\mathrm{m}, 500 \mathrm{~m}$, and $750 \mathrm{~m}$ radii around sampling locations) across all time periods in one season, with panels showing trends within each site $(\mathrm{n}=27)$. Floral resources were calculated with any unknown areas assigned the median floral resource volume from all resource-providing land types in a given spatial scale and time period. 
H2b:
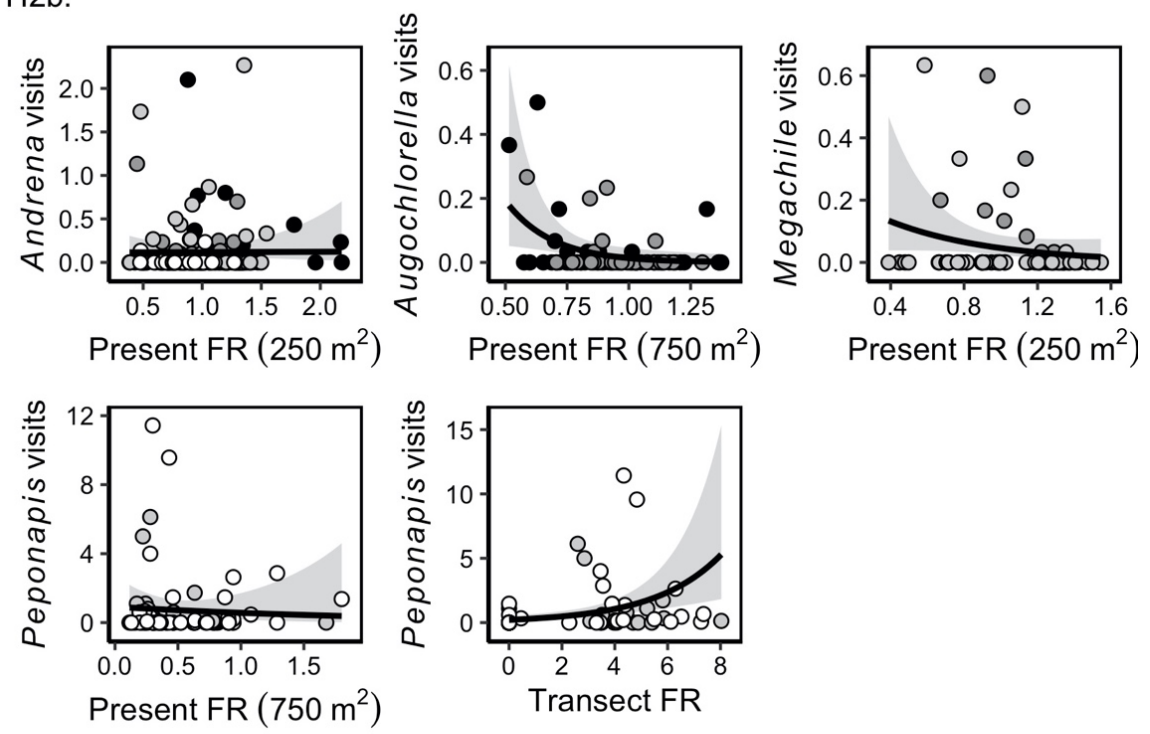

H3a:
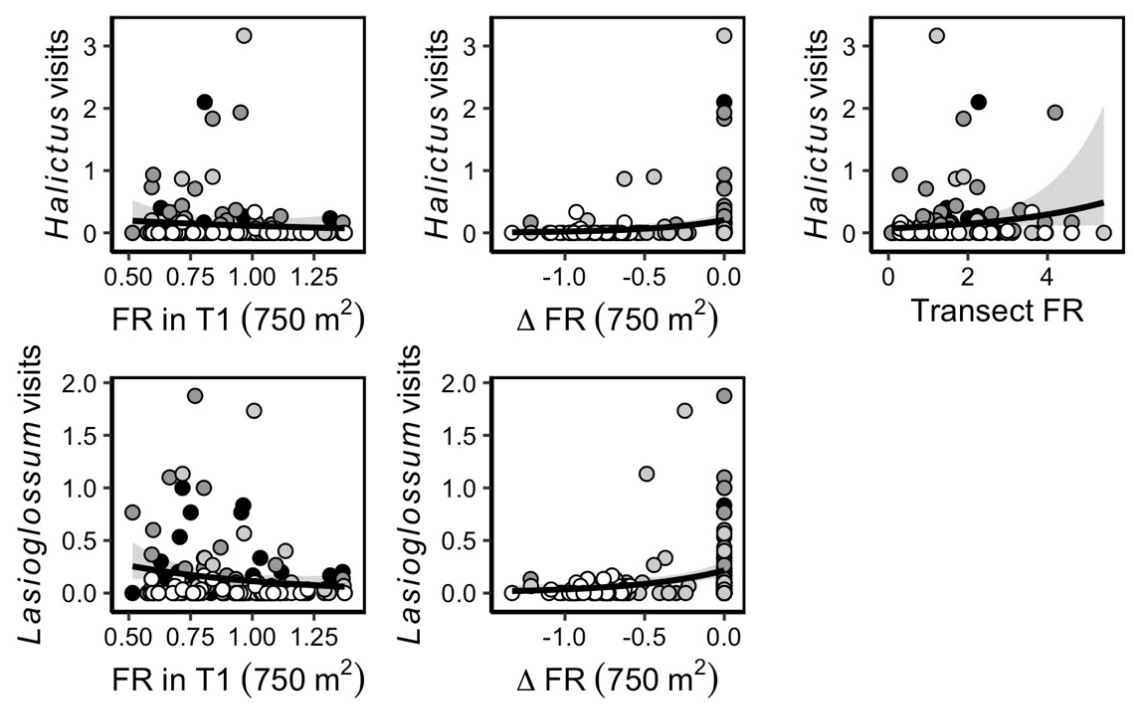

H3b:

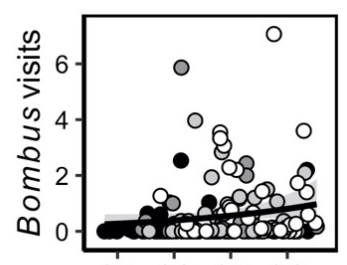
Time
period
- $\mathrm{T} 1$
- T2
o $\mathrm{T} 3$
○ T4

Cumulative FR $\left(250 \mathrm{~m}^{2}\right)$

Fig. 4 Relationship between bee visits and floral resource ('FR') predictors from the best models (in Table 1) measured across four time periods (T1-T4) in four spatial scales (transect, $250 \mathrm{~m}, 500 \mathrm{~m}, 750 \mathrm{~m}$ ) over one season, represented by the corresponding hypotheses: H2b, H3a, or H3b. Lines represent the negative 
binomial relationship between an FR predictor and bee visits, with a $95 \%$ confidence interval. FR were calculated with all unknown areas in a given radius assigned the median volume of FR measured across all known resource-providing land types during a given time period.

\section{Appendix}

Table A1 Land-types used to quantify landscape structure and floral resources around sampling locations. The range in proportion of each land type across all sampling periods is represented as the percent of total area within a 750-m radius around each sampling location. Areas with water, exposed or barren land, and urban or developed land were not digitized, and exact proportions were not calculated for these land types. The unknown crop, hedgerow, and potentially resource-providing crop land types were not assessed for floral resources, and a range is presented for values assigned in models run, from the minimum to the median floral resource volume from all resource-providing land types in a given spatial scale and sampling period.

\begin{tabular}{|c|c|c|c|}
\hline Land type & Description & $\begin{array}{l}\text { Area in } 750-m \text { radius } \\
(\%)\end{array}$ & $\begin{array}{l}\text { Median floral resources } \\
\text { by sampling period } \\
\left(\mathrm{cm}^{3} / \mathrm{m}^{2}\right)\end{array}$ \\
\hline Areas not digitized & $\begin{array}{l}\text { Barren, developed, } \\
\text { exposed, water, urban } \\
\text { land }\end{array}$ & $\mathrm{N} / \mathrm{A}$ & 0.00 \\
\hline Cereal crop & $\begin{array}{l}\text { Barley, millet, oats, } \\
\text { rye, spelt, triticale, } \\
\text { wheat }\end{array}$ & $0.002-15$ & 0.00 \\
\hline Corn & $\begin{array}{l}\text { Anecdotal evidence of } \\
\text { floral resources } \\
\text { provided (but see } \\
\text { Roulston et al. } 2000 \text { ) }\end{array}$ & $0.3-38$ & 0.00 \\
\hline Soybean & $\begin{array}{l}\text { Anecdotal evidence of } \\
\text { floral resources } \\
\text { provided (but see } \\
\text { Erickson et al. 1978, } \\
\text { Ahrent and Caviness } \\
\text { 1994) }\end{array}$ & $1.5-55$ & 0.00 \\
\hline Herbs, field vegetables & $\begin{array}{l}\text { Non-flowering or } \\
\text { harvested before } \\
\text { flowering }\end{array}$ & $0.02-5.4$ & 0.00 \\
\hline Semi-natural & Grass land, shrub land & $0.4-35$ & $\begin{array}{l}0.20 \text { (late-spring) } 2.82 \\
\text { (early-summer) } 1.00 \\
\text { (mid-summer) } 1.53 \\
\text { (late-summer) }\end{array}$ \\
\hline Forage & $\begin{array}{l}\text { Medicago sativa, hay, } \\
\text { pasture, Trifolium spp. }\end{array}$ & $1.7-60$ & $\begin{array}{l}3.67 \text { (late-spring) } 3.49 \\
\text { (early-summer) } 4.23 \\
\text { (mid-summer) } 1.49 \\
\text { (late-summer) }\end{array}$ \\
\hline Forest & & $4.6-87$ & $\begin{array}{l}0.14 \text { (late-spring) } 0.55 \\
\text { (early-summer) }\end{array}$ \\
\hline Apple & Malus pumila & $0.05-4.2$ & 41.6 (late-spring) \\
\hline Asparagus & Asparagus officinalis & $0.01-0.5$ & 0.84 (early-summer) \\
\hline Bean & Phaseolus vulgaris & $0.006-0.5$ & 0.08 (mid-summer) \\
\hline Cucumber & Cucumis sativus & $0.003-0.02$ & 0.28 (late-summer) \\
\hline Melon & Cucumis melo & $0.01-0.8$ & 0.24 (mid-summer) \\
\hline
\end{tabular}




\begin{tabular}{|c|c|c|c|}
\hline Land type & Description & $\begin{array}{l}\text { Area in } 750-m \text { radius } \\
(\%)\end{array}$ & $\begin{array}{l}\text { Median floral resources } \\
\text { by sampling period } \\
\left(\mathrm{cm}^{3} / \mathrm{m}^{2}\right)\end{array}$ \\
\hline Potato & Solanum tuberosum & $0.26-0.29$ & $\begin{array}{l}0.75 \text { (early-summer) } 0.88 \\
\text { (mid-summer) }\end{array}$ \\
\hline Raspberry & $\begin{array}{l}\text { Rubus idaeus, } R . \\
\text { strigosus, } R \text {. occidentalis }\end{array}$ & $0.002-0.9$ & 2.31 (early-summer) \\
\hline Squash & Cucurbita spp. & $0.01-7.1$ & $\begin{array}{l}0.37 \text { (early-summer) } 0.66 \\
\text { (mid-summer) } 1.09 \\
\text { (late-summer) }\end{array}$ \\
\hline Strawberry & Fragaria $\times$ ananassa & $0.5-3.5$ & $\begin{array}{l}12.6 \text { (late-spring) } 13.0 \\
\text { (early-summer) }\end{array}$ \\
\hline Sunflower & Helianthus annuus & $0.005-0.05$ & $\begin{array}{l}31.2 \text { (early-summer) } 33.8 \\
\text { (mid-summer) } 36.3 \\
\text { (late-summer) }\end{array}$ \\
\hline Watermelon & Citrullus lanatus & $0.01-0.2$ & 0.14 (mid-summer) \\
\hline Unknown crop & & $0.08-21$ & $\begin{array}{l}0-1.30 \text { (late-spring) } \\
0-1.57 \text { (early-summer) } \\
0-0.84 \text { (mid-summer) } \\
0-0.54 \text { (late-summer) }\end{array}$ \\
\hline Hedgerow & $\begin{array}{l}\text { Areas bordering } \\
\text { agricultural fields with } \\
\text { shrubs or trees }\end{array}$ & $0.05-6.8$ & $\begin{array}{l}0-1.30 \text { (late-spring) } \\
0-1.57 \text { (early-summer) } \\
0-0.84 \text { (mid-summer) } \\
0-0.54 \text { (late-summer) }\end{array}$ \\
\hline $\begin{array}{l}\text { Potentially } \\
\text { resource-providing crop }\end{array}$ & $\begin{array}{l}\text { Brassica rapa, B. napus, } \\
\text { B. juncea, Capsicum } \\
\text { annuum, Fagopyrum } \\
\text { esculentum, Lycopersicon } \\
\text { esculentum, Physalis } \\
\text { spp., Pisum sativum, } \\
\text { Prunus avium, Pyrus } \\
\text { communis, Rubus } \\
\text { fruticosus }\end{array}$ & $0.002-1.1$ & $\begin{array}{l}0-1.30 \text { (late-spring) } \\
0-1.57 \text { (early-summer) } \\
0-0.84 \text { (mid-summer) } \\
0-0.54 \text { (late-summer) }\end{array}$ \\
\hline
\end{tabular}

Table A2 Measurements and literature sources of floral dimensions for all non-graminoid flowering species. Floral units describe the scale at which species were counted in quadrats (flower, inflorescence, or capitulum in Asteraceae species). ' $l$ ' is length in mm of corolla opening (or receptacle length for capitula), ' $w$ ' is width in mm of corolla opening (or receptacle width for capitula), ' $h$ ' is height in $\mathrm{mm}$, measured from the receptacle to the longest sexual organ (stamen or pistil), and ' $V$ ' is floral volume in $\mathrm{mm}^{3}$, calculated using the formula for volume of an elliptic cylinder $\left(\mathrm{V}=\pi \times \frac{1}{2} \times \frac{\mathrm{w}}{2} \times \mathrm{h}\right)$. Inflorescence volume was calculated by multiplying floral volume by the average number of flowers per inflorescence and was left blank when individual flowers were counted rather than inflorescences. Measurements were made on five individuals per species, or values were obtained from literature sources.

\begin{tabular}{llllllll}
\hline Species & Floral unit & $l$ & $w$ & $h$ & $V$ & Inflorescence $V\left(\mathrm{~mm}^{3}\right)$ & Sources \\
\hline Acer spicatum & inflorescence & 2.0 & 2.0 & 3.0 & 9.42 & 1649 & (Sullivan 1983) \\
Achillea millefolium & inflorescence & 6.0 & 6.0 & 3.4 & 96.1 & 1442 & Measured; https:/ \\
Actaea pachypoda & inflorescence & 2.0 & 2.0 & 5.0 & 15.7 & 298 & (Pellmyr 1985); ht \\
Agrimonia gryposepala & flower & 5.0 & 5.0 & 5.0 & 98.2 & & http://plants.jstor \\
Anthemis arvensis & capitulum & 6.2 & 6.2 & 6.4 & 226 & & Measured
\end{tabular}




\begin{tabular}{|c|c|c|c|c|c|c|c|}
\hline Species & Floral unit & $l$ & $w$ & $h$ & $V$ & Inflorescence $V\left(\mathrm{~mm}^{3}\right)$ & Sources \\
\hline Asclepias syriaca & inflorescence & 2.0 & 2.0 & 2.0 & 6.28 & 126 & Measured \\
\hline Asparagus officinalis & flower & 1.2 & 1.2 & 4.8 & 6.13 & & Measured \\
\hline Barbarea vulgaris & inflorescence & 1.0 & 1.0 & 2.0 & 1.57 & 12.6 & Measured; http:// \\
\hline Capsella bursa-pastoris & inflorescence & 2.0 & 2.0 & 2.0 & 6.28 & 37.7 & (Nave et al. 2016) \\
\hline Cardamine bulbosa & flower & 1.8 & 1.8 & 1.0 & 2.98 & & Measured \\
\hline Cardamine diphylla & flower & 2.0 & 2.8 & 7.0 & 29.5 & & Measured \\
\hline Centaurea sp. & capitulum & 8.0 & 8.0 & 22.0 & 1143 & & Measured \\
\hline Cerastium fontanum & flower & 1.0 & 1.0 & 3.6 & 2.83 & & Measured \\
\hline Chelidonium sp. & flower & 5.0 & 5.0 & 8.0 & 157 & & (Kang et al. 1991) \\
\hline Cichorium intybus & capitulum & 4.6 & 4.6 & 9.4 & 161 & & Measured \\
\hline Citrullus lanatus & flower & 5.0 & 5.0 & 5.2 & 102 & & Measured \\
\hline Coptis trifolia & flower & 7.6 & 7.6 & 4.2 & 197 & & Measured \\
\hline Cornus canadensis & flower & 7.8 & 7.8 & 4.0 & 193 & & Measured \\
\hline Cornus sericea & inflorescence & 1.0 & 1.0 & 5.4 & 4.24 & 106 & Measured; http:// \\
\hline Cucumis melo & flower & 7.5 & 7.5 & 4.5 & 199 & & http://www.eflora \\
\hline Cucumis sativus & flower & 2.0 & 2.0 & 6.2 & 19.5 & & Measured \\
\hline Cucurbita pepo (female zucchini) & flower & 10.2 & 10.2 & 16.6 & 1353 & & Measured \\
\hline Cucurbita pepo (male zucchini) & flower & 8.4 & 8.4 & 16.0 & 934 & & Measured \\
\hline Cucurbita pepo (zucchini) & flower & 9.3 & 9.3 & 16.3 & 1107 & & Measured \\
\hline Cucurbita sp. (female squash) & flower & 13.8 & 13.8 & 19.8 & 3091 & & Measured \\
\hline Cucurbita sp. (male squash) & flower & 10.4 & 8.4 & 15.8 & 1127 & & Measured \\
\hline Cucurbita sp. (squash) & flower & 12.1 & 11.1 & 17.8 & 1878 & & Measured \\
\hline Cucurbita spp. & flower & 10.7 & 10.2 & 17.1 & 1461 & & Measured \\
\hline Cucurbita spp. (female) & flower & 12.0 & 12.0 & 18.2 & 2058 & & Measured \\
\hline Cucurbita spp. (male) & flower & 9.4 & 8.4 & 15.9 & 986 & & Measured \\
\hline Daucus carota & inflorescence & 2.0 & 2.0 & 1.0 & 3.14 & 358 & Measured; (Sivin: \\
\hline Echium vulgare & flower & 2.4 & 3.8 & 9.2 & 65.5 & & Measured \\
\hline Erigeron canadensis & inflorescence & 1.0 & 1.0 & 3.0 & 2.36 & 1275 & Measured \\
\hline Erigeron philadelphicus & capitulum & 7.6 & 7.6 & 3.4 & 157 & & Measured \\
\hline Erigeron sp. & capitulum & 3.55 & 3.55 & 12.6 & 52.5 & & Measured \\
\hline Erysimum cheiranthoides & inflorescence & 1.0 & 1.0 & 3.0 & 2.36 & 18.8 & (Idris and Grafius \\
\hline Erythronium americanum & flower & 3.0 & 3.0 & 11.0 & 77.8 & & Measured \\
\hline Euthamia graminifolia & inflorescence & 1.0 & 1.0 & 1.0 & 0.79 & 20.4 & (Harder 1985); htt \\
\hline Fagopyrum esculentum & inflorescence & 2.0 & 2.0 & 2.0 & 6.28 & 980 & (Cawoy et al. 2006 \\
\hline Fragaria $\times$ ananassa & flower & 7.8 & 7.8 & 6.2 & 304 & & Measured \\
\hline Fragaria virginiana & flower & 3.0 & 3.0 & 2.4 & 26.4 & & Measured \\
\hline Galinsoga quadriradiata & capitulum & 2.0 & 2.0 & 2.0 & 0.01 & & (Warwick and S \\
\hline Galium mollugo & inflorescence & 1.0 & 1.0 & 1.0 & 0.79 & 14.1 & https://weedecolo \\
\hline Galium palustre & inflorescence & 1.0 & 1.0 & 1.0 & 0.79 & 5.50 & https://weedecolos \\
\hline Geum aleppicum & flower & 6.0 & 6.0 & 8.0 & 226 & & http://symbiota.m \\
\hline Glechoma hederacea & flower & 1.0 & 1.0 & 9.8 & 7.70 & & Measured \\
\hline Helianthus annuus & capitulum & 35.4 & 35.4 & 20.7 & 27435 & & Measured \\
\hline Hieracium caespitosum & capitulum & 7.4 & 7.4 & 3.4 & 153 & & Measured \\
\hline Hieracium pilosella & capitulum & 10.4 & 10.4 & 6.4 & 538 & & Measured \\
\hline Lactuca sp. & capitulum & 2.0 & 2.0 & 3.0 & 9.42 & & http://www.natur \\
\hline Leucanthemum vulgare & capitulum & 10.5 & 10.5 & 3.5 & 311 & & Measured \\
\hline Linaria vulgaris & flower & 2.4 & 1.0 & 20.6 & 39.1 & & Measured \\
\hline Lotus corniculatus & flower & 4.73 & 4.73 & 12.0 & 211 & & http://ucjeps.berk \\
\hline Maianthemum canadense & inflorescence & 1.0 & 1.0 & 1.0 & 0.79 & 14.9 & http://plants.jstor \\
\hline Malus pumila & flower & 9.2 & 9.4 & 9.8 & 674 & & Measured \\
\hline
\end{tabular}




\begin{tabular}{|c|c|c|c|c|c|c|c|}
\hline Species & Floral unit & $l$ & $w$ & $h$ & $V$ & Inflorescence $V\left(\mathrm{~mm}^{3}\right)$ & Sources \\
\hline Malva neglecta & flower & 1.9 & 1.9 & 4.25 & 12.0 & & (Nave et al. 2016) \\
\hline Medicago lupulina & inflorescence & 1.0 & 1.0 & 1.0 & 0.79 & 11.8 & Measured; http:// \\
\hline Medicago sativa & inflorescence & 1.0 & 1.0 & 5.0 & 3.93 & 68.7 & Measured; (Winkle \\
\hline Mitella diphylla & flower & 1.0 & 1.0 & 3.0 & 2.36 & & Measured \\
\hline Oenothera biennis & flower & 1.0 & 1.0 & 6.4 & 5.03 & & Measured \\
\hline Oxalis stricta & flower & 1.0 & 1.0 & 3.5 & 2.75 & & Measured \\
\hline Phaseolus vulgaris & flower & 2.8 & 2.8 & 7.6 & 48.2 & & Measured \\
\hline Physalis heterophylla & flower & 2.8 & 2.8 & 9.0 & 58.1 & & Measured \\
\hline Plantago lanceolata & inflorescence & 1.0 & 1.0 & 2.0 & 6.28 & 452 & (Cavers et al. 1980 \\
\hline Potentilla argentea & flower & 2.4 & 2.4 & 1.2 & 6.13 & & Measured \\
\hline Prunella vulgaris & flower & 1.2 & 1.6 & 7.0 & 11.2 & & Measured \\
\hline Ranunculus acris & flower & 5.8 & 5.8 & 2.8 & 80.9 & & Measured \\
\hline Ranunculus recurvatus & flower & 1.6 & 1.6 & 2.6 & 6.28 & & Measured \\
\hline Rubus allegheniensis & flower & 11.6 & 11.6 & 4.6 & 489 & & Measured \\
\hline Rubus sp. (raspberry) & flower & 6.4 & 6.4 & 6.0 & 202 & & Measured \\
\hline Rudbeckia hirta & capitulum & 15.0 & 15.0 & 3.6 & 636 & & http://www.efloras \\
\hline Silene vulgaris & flower & 3.2 & 3.2 & 15.6 & 133 & & Measured \\
\hline Sisyrinchium montanum & flower & 1.0 & 1.0 & 4.5 & 3.53 & & Measured \\
\hline Solanum tuberosum & flower & 2.8 & 2.8 & 9.0 & 57.3 & & Measured \\
\hline Solidago canadensis & inflorescence & 1.0 & 1.0 & 1.0 & 0.79 & 26.7 & Measured; (Harder \\
\hline Solidago sp. & inflorescence & 1.0 & 1.0 & 1.0 & 0.79 & 26.7 & Measured; (Harder \\
\hline Sonchus arvensis & capitulum & 10.5 & 10.5 & 22 & 1905 & & (Lemna and Messe \\
\hline Symphotrichum lanceolatum & capitulum & 4.0 & 4.0 & 6.0 & 75.4 & & (Chmielewski and \\
\hline Taraxacum agg. & capitulum & 19.6 & 19.6 & 8.4 & 3050 & & Measured \\
\hline Trifolium aureum & inflorescence & 1.0 & 1.0 & 7.0 & 5.50 & 179 & http://www.efloras \\
\hline Trifolium pratense & inflorescence & 1.0 & 1.0 & 11.0 & 8.64 & 432 & (Winkler et al. 200 \\
\hline Trifolium repens & inflorescence & 1.0 & 1.0 & 2.0 & 1.57 & 55.0 & (Nave et al. 2016); \\
\hline Trillium erectum & flower & 8.0 & 8.0 & 9.0 & 452 & & http://www.eflora \\
\hline Trillium grandiflorum & flower & 5.4 & 5.6 & 11.0 & 292 & & Measured \\
\hline Verbena hastata & inflorescence & 1.0 & 1.0 & 2.0 & 1.57 & 8.80 & Measured \\
\hline Veronica serpyllifolia & flower & 1.0 & 1.0 & 1.13 & 0.88 & & Measured \\
\hline Veronica sp. & flower & 1.04 & 1.04 & 1.04 & 0.88 & & Measured \\
\hline Vicia cracca & inflorescence & 3.0 & 3.0 & 6.2 & 43.8 & 1972 & Measured; http://1 \\
\hline Viola pubescens & flower & 1.0 & 1.0 & 4.5 & 3.53 & & Measured \\
\hline
\end{tabular}

Table A3 Literature values for nectar production in 46 flowering species. "Nectar unit" is the scale at which nectar was collected from species, with capitulum measurements for members of Asteraceae and individual flower measurements for all other species. "Source species" were used when nectar production values were only available for morphologically similar species within the same genus and is left blank when the species itself was used.

\begin{tabular}{|c|c|c|c|c|}
\hline Species & Nectar ( $\mu \mathrm{g} /$ day $)$ & Nectar unit & Source species & Source \\
\hline Acer spicatum & 77.0 & flower & & (Heinrich 1976) \\
\hline Achillea millefolium & 38.1 & capitulum & & (Holl 1995, Hicks et al. 2016) \\
\hline Agrimonia gryposepala & 1.37 & flower & A. eupatoria & (Baude et al. 2016) \\
\hline Anthemis arvensis & 2880 & capitulum & & (Schultz and Dlugosch 1999) \\
\hline Asclepias syriaca & 1750 & flower & & (Heinrich 1976) \\
\hline Barbarea vulgaris & 158 & flower & & (Holl 1995) \\
\hline Capsella bursa-pastoris & 0.39 & flower & & (Baude et al. 2016) \\
\hline
\end{tabular}




\begin{tabular}{|c|c|c|c|c|}
\hline Species & Nectar ( $\mu \mathrm{g} /$ day $)$ & Nectar unit & Source species & Source \\
\hline Cardamine bulbosa & 4.50 & flower & C. spp. & (Baude et al. 2016) \\
\hline Centaurea sp. & 1474 & capitulum & C. nigra & (Hicks et al. 2016) \\
\hline Cerastium fontanum & 26.9 & flower & & (Baude et al. 2016) \\
\hline Citrullus lanatus & 12000 & flower & & (Taha and Bayoumi 2009) \\
\hline Cornus sericea & 68.8 & flower & C. sanguinea & (Baude et al. 2016) \\
\hline Cucurbita sp. (female squash) & 30810 & flower & C. реро & (Vidal et al. 2006) \\
\hline Daucus carota & 7.35 & flower & & (Baude et al. 2016) \\
\hline Echium vulgare & 688 & flower & & (Hicks et al. 2016) \\
\hline Erigeron philadelphicus & 2250 & capitulum & & (Holl 1995) \\
\hline Euthamia graminifolia & 24.0 & capitulum & & (Heinrich 1976) \\
\hline Fragaria virginiana & 42.0 & flower & & (Heinrich 1976) \\
\hline Galium mollugo & 3.58 & flower & & (Baude et al. 2016) \\
\hline Geum aleppicum & 29.8 & flower & G. urbanum & (Baude et al. 2016) \\
\hline Glechoma hederacea & 94.4 & flower & & (Baude et al. 2016) \\
\hline Leucanthemum vulgare & 515 & capitulum & & (Hicks et al. 2016) \\
\hline Linaria vulgaris & 544 & flower & & (Baude et al. 2016) \\
\hline Lotus corniculatus & 61.8 & flower & & (Baude et al. 2016) \\
\hline Malus pumila & 110 & flower & & (Baude et al. 2016) \\
\hline Malva neglecta & 541 & flower & M. moschata & (Hicks et al. 2016) \\
\hline Medicago lupulina & 1.63 & flower & & (Baude et al. 2016) \\
\hline Medicago sativa & 146 & flower & & (Baude et al. 2016) \\
\hline Oxalis stricta & 15.5 & flower & O. acetosella & (Baude et al. 2016) \\
\hline Phaseolus vulgaris & 53.4 & flower & Cultivated bean & (Baude et al. 2016) \\
\hline Potentilla argentea & 23.3 & flower & Potentilla spp. & (Baude et al. 2016) \\
\hline Prunella vulgaris & 139 & flower & & (Baude et al. 2016) \\
\hline Ranunculus acris & 78.8 & flower & & (Baude et al. 2016) \\
\hline Rubus allegheniensis & 894 & flower & & (Holl 1995) \\
\hline Rubus sp. (raspberry) & 1893 & flower & R. fruticosus agg. & (Baude et al. 2016) \\
\hline Silene vulgaris & 251 & flower & & (Baude et al. 2016) \\
\hline Solanum tuberosum & 27.3 & flower & & (Baude et al. 2016) \\
\hline Solidago canadensis & 28.8 & capitulum & & (Heinrich 1976) \\
\hline Sonchus arvensis & 651 & capitulum & & (Baude et al. 2016) \\
\hline Symphotrichum lanceolatum & 1116 & capitulum & & (Chmielewski and Semple 2001) \\
\hline Taraxacum agg. & 2137 & capitulum & & (Hicks et al. 2016) \\
\hline Trifolium pratense & 117 & flower & & (Baude et al. 2016) \\
\hline Trifolium repens & 49.0 & flower & & (Baude et al. 2016) \\
\hline Veronica serpyllifolia & 2.83 & flower & & (Baude et al. 2016) \\
\hline Vicia cracca & 484 & flower & & (Baude et al. 2016) \\
\hline Viola pubescens & 125 & flower & Viola spp. & (Holl 1995, Baude et al. 2016) \\
\hline
\end{tabular}

Table A4 Literature values for pollen volume in 33 flowering species. Pollen volume was provided in literature sources directly or was calculated from literature values of pollen grain counts and pollen grain volumes. "Floral unit" is the scale at which pollen was collected from species, with capitulum measurements for members of Asteraceae and individual flower measurements for all other species. "Source species" were used when pollen production values were only available for morphologically similar species within the same genus and is left blank when the species itself was used. 


\begin{tabular}{|c|c|c|c|}
\hline Species & Pollen ( $\mu$ l/floral unit) & Source species & Literature source \\
\hline Acer spicatum & 0.02 & & $\begin{array}{l}\text { (Biesboer 1975, } \\
\text { Sullivan 1983) }\end{array}$ \\
\hline Achillea millefolium & 1.13 & & (Hicks et al. 2016) \\
\hline Actaea pachypoda & 0.52 & & $\begin{array}{l}\text { (Pellmyr 1985); } \\
\text { http://www.discoverlife.org }\end{array}$ \\
\hline Capsella bursa-pastoris & 0.001 & & (Hicks et al. 2016) \\
\hline Centaurea sp. & 6.40 & C. nigra & (Hicks et al. 2016) \\
\hline Cerastium fontanum & 0.04 & & (Hicks et al. 2016) \\
\hline Cucumis melo & 0.13 & & $\begin{array}{l}\text { (Perveen and Qaiser } \\
2008, \text { Kouonon et al. } \\
2009 \text { ) }\end{array}$ \\
\hline $\begin{array}{l}\text { Cucurbita pepo } \\
\text { (zucchini) }\end{array}$ & 13.1 & & $\begin{array}{l}\text { (Nepi and Pacini } 1993, \\
\text { Vidal et al. 2006) }\end{array}$ \\
\hline Cucurbita sp. (squash) & 34.8 & & (Vidal et al. 2006) \\
\hline Daucus carota & 0.02 & & (Hicks et al. 2016) \\
\hline Echium vulgare & 0.15 & & (Hicks et al. 2016) \\
\hline Erythronium & 16.3 & & (Harder et al. 1985, \\
\hline americanum & & & Kosenko 1999) \\
\hline Fagopyrum esculentum & 0.06 & & (Cawoy et al. 2006) \\
\hline Fragaria virginiana & 1.42 & & $\begin{array}{l}\text { (Hebda et al. 1988, } \\
\text { Ashman and Hitchens } \\
2000 \text { ) }\end{array}$ \\
\hline Galium mollugo & 0.007 & G. verum, G. album & (Hicks et al. 2016) \\
\hline Galium palustre & 0.007 & G. verum, G. album & (Hicks et al. 2016) \\
\hline Glechoma hederacea & 0.06 & & $\begin{array}{l}\text { (Hutchings and Price } \\
\text { 1999, Moon et al. } \\
\text { 2008) }\end{array}$ \\
\hline Leucanthemum vulgare & 15.9 & & (Hicks et al. 2016) \\
\hline Linaria vulgaris & 0.44 & & $\begin{array}{l}\text { (Olsson 1974, Arnold } \\
\text { 1982) }\end{array}$ \\
\hline Lotus corniculatus & 0.15 & & (Hicks et al. 2016) \\
\hline Malva neglecta & 0.58 & & $\begin{array}{l}\text { (Cruden 1977); } \\
\text { http://blogs.cornell.edu/pollengrains/ }\end{array}$ \\
\hline Medicago sativa & 0.16 & & (Müller et al. 2006) \\
\hline Oenothera biennis & 8.00 & & $\begin{array}{l}\text { (Cruden and Jensen } \\
\text { 1979, Hall et al. 1988) }\end{array}$ \\
\hline Plantago lanceolata & 0.01 & & (Hicks et al. 2016) \\
\hline Prunella vulgaris & 0.03 & & (Hicks et al. 2016) \\
\hline Ranunculus acris & 1.40 & & (Hicks et al. 2016) \\
\hline Silene vulgaris & 0.36 & S. dioica, S. latifolia & (Hicks et al. 2016) \\
\hline Sonchus arvensis & 0.94 & S. asper & (Hicks et al. 2016) \\
\hline Trifolium aureum & 2.82 & & (Hicks et al. 2016) \\
\hline Trifolium repens & 0.02 & & (Hicks et al. 2016) \\
\hline Trillium erectum & 0.03 & & (Hicks et al. 2016) \\
\hline Veronica sp. & 0.03 & $V \cdot$ persica & (Hicks et al. 2016) \\
\hline Vicia cracca & 0.04 & & (Hicks et al. 2016) \\
\hline
\end{tabular}

